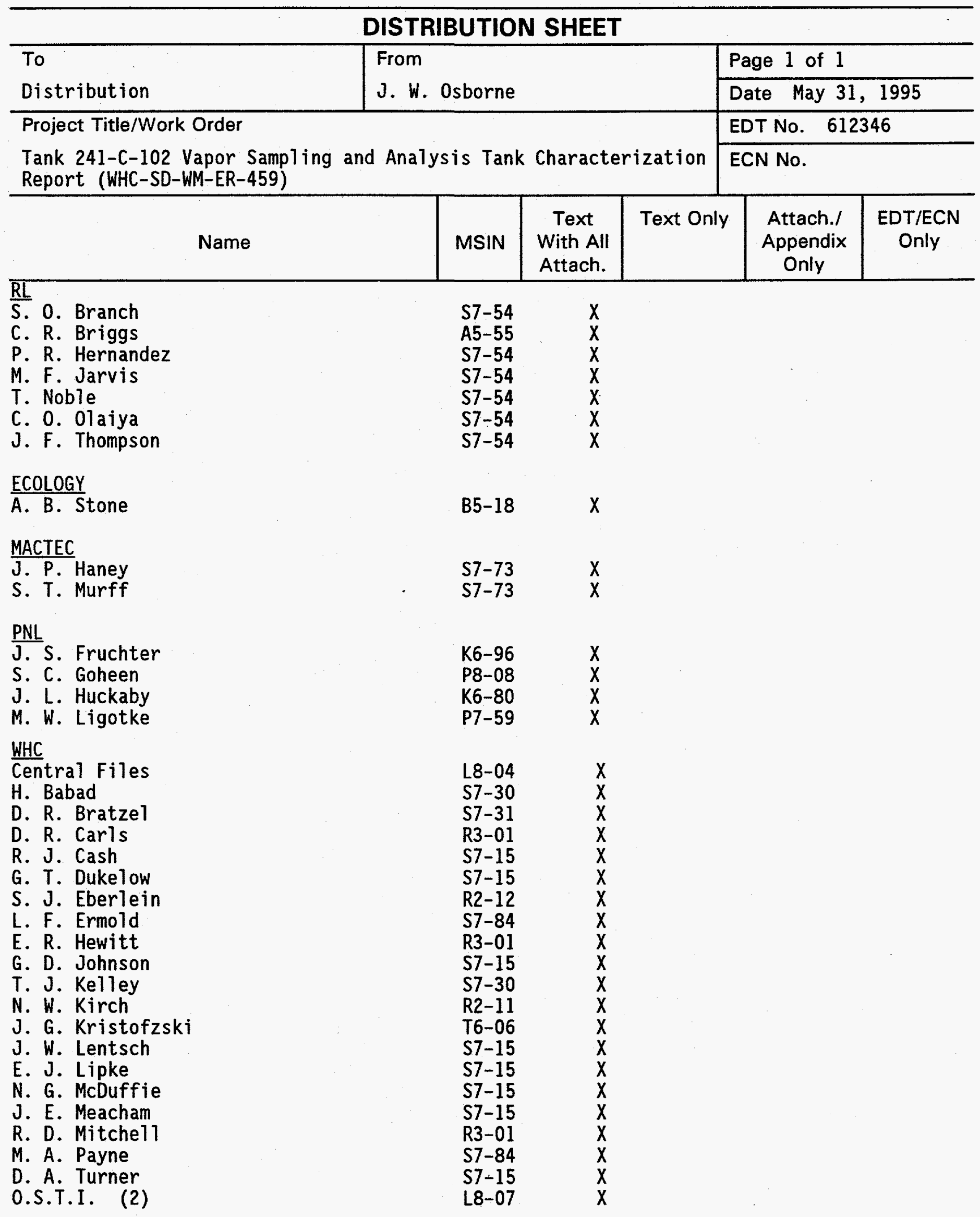




\section{DISCLAIMER}

This report was prepared as an account of work sponsored by an agency of the United States Government. Neither the United States Government nor any agency thereof, nor any of their employees, make any warranty, express or implied, or assumes any legal liability or responsibility for the accuracy, completeness, or usefulness of any information, apparatus, product, or process disclosed, or represents that its use would not infringe privately owned rights. Reference herein to any specific commercial product, process, or service by trade name, trademark, manufacturer, or otherwise does not necessarily constitute or imply its endorsement, recommendation, or favoring by the United States Government or any agency thereof. The views and opinions of authors expressed herein do not necessarily state or reflect those of the United States Government or any agency thereof. 


\section{DISCLAIMER}

Portions of this document may be illegible in electronic image products. Images are produced from the best available original document. 


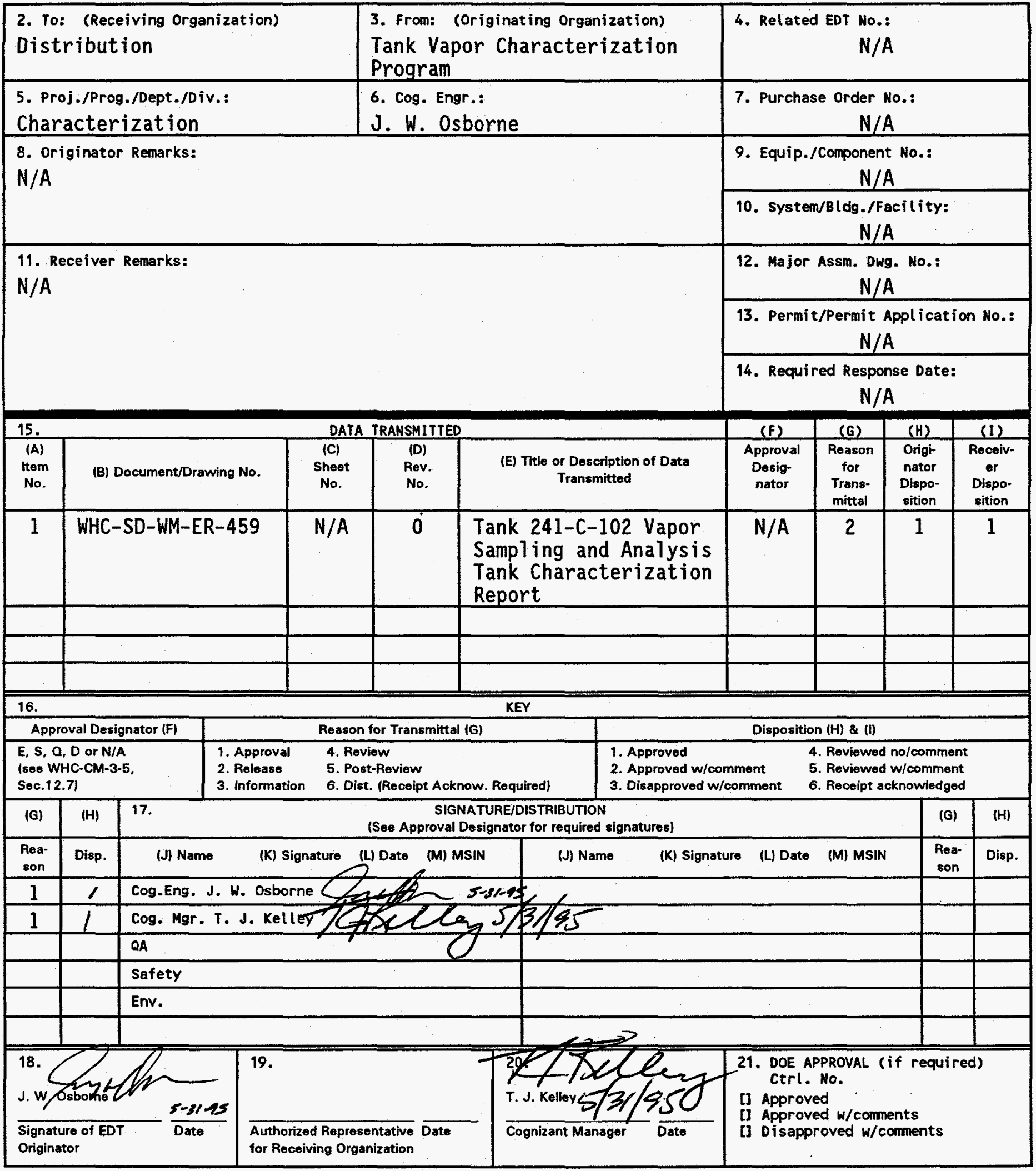




\section{RELEASE AUTHORIZATION}

Document Number: WHC-SD-WM-ER-459, REV 0

Document Title: Tank 241-C-102 Vapor Sampling and Analys is Tank Characterization Report

Release Date: $\quad 5 / 31 / 95$

This document was reviewed following the procedures described in WHC-CM-3-4 and is:

APPROVED FOR PUBLIC RELEASE

WHC Information Release Administration Specialist:

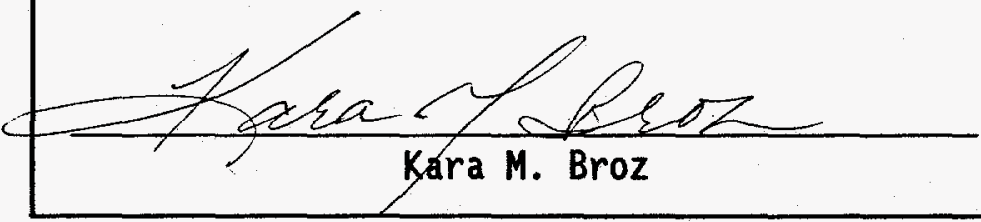

May 31,1995

TRADEMARK DISCLAIMER. Reference herein to any specific commercial product, process, or service by trade name, trademark, manufacturer, or otherwise, does not necessarily consti tute or imply its endorsement, recomendation, or favoring by the United States Government or any agency thereof or its contractors or subcontractors.

This report has been reproduced from the best available copy. Available in paper copy and microfiche. Printed in the United States of America. Available to the U.S. Department of Energy and its contractors from:

U.S. Department of Energy

Office of Scientific and Technical Information (OSTI)

P.0. Box 62

Oak Ridge, TN 37831

Telephone: (615) 576-8401

Available to the public from:

U.S. Department of Commerce

National Technical Information Service (UTIS)

5285 Port Royal Road

Springfield, VA 22161

Telephone: (703) 487-4650 
2. Title

Tank 241-C-102 Vapor Sampling and Analysis Tank Characterization Report

\section{Key Hords}

241-C-102, Headspace vapor samples, organic analytes, VSS, SUMMA ${ }^{\text {TM }}$, inorganic gases and vapors
3. Number

WHC-SD-WM-ER-459 4. Rev No. 0

\section{Author}

Name: J. L. Huckaby

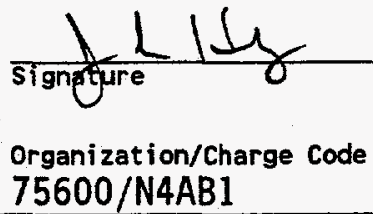

\title{
7. Abstract
}

Tank 241-C-102 headspace gas and vapor samples were collected and analyzed to help determine the potential risks to tank farm workers due to fugitive emissions from the tank. The drivers and objectives of waste tank headspace sampling and analysis are discussed in "Program Plan for the Resolution of Tank Vapor Issues" (Osborne and Huckaby 1994). Tank 241-C-102 was vapor sampled in accordance with "Data Quality Objectives for Generic In-Tank Health and Safety Issue Resolution (Osborne et al., 1994).

\section{DISCLAIMER}

\begin{abstract}
This report was prepared as an account of work sponsored by an agency of the United States Government. Neither the United States Government nor any agency thereof, nor any of their employees, makes any warranty, express or implied, or assumes any legal liability or responsibility for the accuracy, completeness, or usefulness of any information, apparatus, product, or process disclosed, or represents that its use would not infringe privately owned rights. Reference herein to any specific commercial product, process, or service by trade name, trademark, manufacturer, or otherwise does not necessarily constitute or imply its endorsement, recommendation, or favoring by the United States Government or any agency thereof. The views and opinions of authors expressed herein do not necessarily state or reflect those of the United States Government or any agency thereof.
\end{abstract}

8. RELEASE STAMP

OFFICIAL RELEASE BYWHC

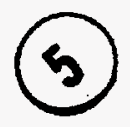
DATE MAY 311995 Sta. 4 
WHC-SD-WM-ER-459 REV. 0

\section{Tank 241-C-102 Vapor Sampling and Analysis Tank Characterization Report}

\section{X.0 INTRODUCTION}

Tank C-102 headspace gas and vapor samples were collected and analyzed to help determine the potential risks of fugitive emissions to tank farm workers. The drivers and objectives of waste tank headspace sampling and analysis are discussed in Program Plan for the Resolution of Tank Vapor Issues (Osborne and Huckaby 1994). Tank C-102 was vapor sampled in accordance with Data Quality Objectives for Generic In-Tank Health and Safety Issue Resolution (Osborne et al. 1994). Results presented here represent the best available data on the headspace constituents of tank $\mathrm{C}-102$.

\section{X.1 VENTILATION SYSTEM CONSIDERATIONS}

Gas and vapor concentrations in tank C-102 are influenced by its connections to other tanks and its ventilation pathways. Tank $\mathrm{C}-102$ is the central tank in a 3-tank cascade with tanks $\mathrm{C}-101$ and $\mathrm{C}-103$, and is connected to these tanks via 7.4-cm (2.9-in.) inside diameter, 7.6-m (25-ft) long cascade lines. These 3 waste tanks are passively ventilated, which means that they are allowed to exhale air, waste gases, and vapors as the barometric pressure falls, and inhale ambient air as the barometric pressure rises.

Barometric pressure typically rises and falls on a diurnal cycle, with an average daily exchange of air equal to about $0.46 \%$ of each tank headspace (Huckaby 1994). When headspace samples were collected from these tanks, tanks C-102 and C-103 also received sma11 streams of dry ambient air to protect waste surface level instruments from condensation of water vapor. The flowrate of this instrument air varied from about 1.4 to $1.7 \mathrm{~m}^{3} / \mathrm{hr}$ (50 to 60 $\mathrm{ft}^{3} / \mathrm{hr}$ ), (Huckaby 1994).

The breather riser on tank C-101 was valved shut in December 1989 , so that any air exchange with the atmosphere would occur via the cascade line to tank C102. Furthermore, since December 1989 the cascade of tanks C-101, C-102, and C-103 has had only 1 breather riser open (either on tank C-102 or tank C-103). In the period before headspace samples were collected from tank C-102 (specifically since March 1993), the breather riser on tank C-103 had been valved shut, and the intended pathway for tanks $C-101, C-102$, and $C-103$ to breathe with the atmosphere was via the breather riser on tank C-102 (Conrad 1994).

Anderson (1990) notes, however, that the cascade line between tanks C-101 and C-102 was partially plugged in 1954 . A comparison of vapor data indicates that the cascade line between tanks $C-101$ and $C-102$ does not effectively transport organic vapors, and may be blocked (Huckaby 1995a). To determine the origin of gases and vapors in tank $\mathrm{C}-102$, it is important to understand 
WHC-SD-WM-ER-459 REV. 0

the extent to which tanks $\mathrm{C}-101$ and $\mathrm{C}-103$ breathe through tank $\mathrm{C}-102$, because constituents detected in the headspace of tank $C-102$ may actually have originated from the waste in tanks $C-101$ or $C-103^{1}$. Sections $X .3 .4$ and $X .4 .4$ discuss what the available headspace data from tanks $C-101, C-102$, and $C-103$ indicate about whether tanks $\mathrm{C}-101$ and $\mathrm{C}-103$ breathe freely via their cascade lines with tank $\mathrm{C}-102$.

\section{X.2 SAMPLING EVENT}

Headspace gas and vapor samples were collected from tank $\mathrm{C}-102$ using the vapor sampling system (VSS) on August 23, 1994 by WHC Sampling and Mobile Laboratories (WHC 1995). Sample collection and analys is were performed as directed by the sample and analysis plan (WHC 1995, Appendix A). The tank headspace temperature was determined to be $25.8{ }^{\circ} \mathrm{C}$. Air from the $\mathrm{C}-102$ headspace was withdrawn via a $6.1-\mathrm{m}$ long heated sampling probe mounted in riser 3 , and transferred via heated tubing to the VSS sampling manifold. Heated zones of the VSS were maintained at approximately $50{ }^{\circ} \mathrm{C}$. All samples were collected between 12:46 p.m. and 4:20 p.m., with no anomalies noted.

Sampling media were prepared and analyzed by WHC, Oak Ridge National Laboratories (ORNL), Pacific Northwest Laboratories (PNL), and Oregon Graduate Institute of Science and Technology (OGIST) through a contract with Sandia National Laboratories. The 39 tank air samples and 2 ambient air control samples collected are listed in Table $X-1$ by analytical laboratory. Table $X-1$ also lists the 14 trip blanks and 2 field blanks provided by the laboratories.

A general description of vapor sampling and sample analysis methods is given by Huckaby (1995b). The sampling equipment, sample collection sequence, sorbent trap sample air flow rates and flow times, chain of custody information, and a discussion of the sampling event itself are given in WHC 1995 and references therein.

\section{X.3 INORGANIC GASES AND VAPORS}

Analytical results of sorbent trap and SUMMA ${ }^{T M, 2}$ canister tank air samples for selected inorganic gases and vapors are given in Table $X-2$ in parts per million by volume (ppmv) in dry air. Inorganic analyte sorbent traps were prepared and analyzed by PNL (Klinger et al. 1995a), and SUMMA ${ }^{\text {TM }}$ canisters were analyzed for inorganic analytes by OGIST (Rasmussen 1994a).

1 Tank $\mathrm{C}-103$ is known to have a layer of semivolatile organic liquid floating on the aqueous waste (Pool and Bean 1994), and the highest total concentration of organic vapors of any waste tank known (Huckaby and Story 1994).

2 SUMMA is a trademark of Molectrics, Inc., Cleveland, Ohio. 
WHC-SD-WM-ER-459 REV. 0

\section{X.3.1 Ammonia, Hydrogen, and Nitrous Oxide}

The reported ammonia concentration, $189 \mathrm{ppmv}$, is over 7 times the National Institute of Occupational Safety and Health (NIOSH) 8-hr recommended exposure limit (REL) of 25 ppmv for ammonia (NIOSH 1995). Ammonia has been observed in virtually all of the waste tanks sampled to date, at concentrations ranging from about 3 ppmv in tank C-108 (Lucke et a1. 1995a), to $1040 \mathrm{ppmv}$ in BY-108 (McVeety et a1. 1995).

The concentration of hydrogen in tank C-102 was determined to be $133 \mathrm{ppmv}$. Hydrogen in the waste tanks is of concern as a fuel. Given that the lower flammability limit (LFL) for hydrogen in air is about $4 \%$ by volume, the 133 ppmv hydrogen concentration in tank $\mathrm{C}-102$ corresponds to about $0.3 \%$ of its LFL. At this level hydrogen is not a flammability concern in tank C-102.

The nitrous oxide concentration in tank $C-102,154$ ppmv, is over 6 times the NIOSH 8-hr REL of 25 ppmv for nitrous oxide (NIOSH 1995). Nitrous oxide has been detected in other waste tanks at concentrations as low as about $12 \mathrm{ppmv}$ in tank TX-105 (Klinger et al. 1995b), and as high as about 800 ppmv in tank C-103 (Huckaby and Story 1994).

\section{X.3.2 Carbon Monoxide and Carbon Dioxide}

Carbon monoxide in the tank $\mathrm{C}-102$ headspace, measured to be $4.0 \mathrm{ppmv}$ in SUMMA ${ }^{T M}$ samples (Rasmussen 1994a), is much higher than in ambient air, where it typically ranges from 0.05 to $0.15 \mathrm{ppmv}$. Because different analytical methods have been used to measure carbon monoxide in the waste tanks sampled to date, the information on carbon monoxide has varied from tank to tank. Elevated waste tank headspace carbon monoxide concentrations are common, and are thought to be due to the decomposition of organic waste in the tanks. The 4.0 ppmv of carbon monoxide in tank $\mathrm{C}-102$ is the third highest measured in any waste tank to date; tanks $\mathrm{C}-103$ and $\mathrm{C}-101$ were determined to have $26.7 \mathrm{ppmv}$ and $15.5 \mathrm{ppmv}$, respectively, of carbon monoxide (Huckaby and Story 1994,

Huckaby 1995a). The 4.0 ppmv of carbon monoxide in tank $\mathrm{C}-102$ is less than the NIOSH 8-hr REL of 35 ppmv.

The average carbon dioxide concentration in the tank $\mathrm{C}-102$ headspace, 8.2 ppmv, is among the lowest measured in any waste tank to date. Normally present in the ambient air at a concentration of 350 to $400 \mathrm{ppmv}$, carbon dioxide is typically at a lower concentration in the waste tank headspaces than in ambient air. Carbon dioxide introduced by air exchange with the atmosphere is readily absorbed by caustic supernatant and interstitial liquids of the waste tanks, and converted to carbonate in solution.

\section{X.3.3 Nitric Oxide, Nitrogen Dioxide, Water and Tritium}

Nitric oxide and nitrogen dioxide concentrations in the tank C-102 headspace were determined to be $0.24 \mathrm{ppmv}$ and $\leq 0.05 \mathrm{ppmv}$, respectively. These are both acid gases that would have very low equilibrium concentrations above the high $\mathrm{pH}$ sludge in tank $\mathrm{C}-102$. The measurable presence of nitric oxide may be due 
WHC-SD-WM-ER-459 REV. 0

to $i$ ts formation from oxygen and nitrogen in the radiation field of the headspace. The NIOSH 8-hr REL is $25 \mathrm{ppmv}$ for nitric oxide, and the 15-minute short term exposure limit (STEL) for nitrogen dioxide is $1 \mathrm{ppmv}$.

The water vapor concentration of tank $C-102$ was determined to be about 20.4 $\mathrm{mg} / \mathrm{L}$, at the tank headspace temperature of $25.8{ }^{\circ} \mathrm{C}$ and pressure of $990 \mathrm{mbar}$ (742.7 torr), (WHC 1995). This corresponds to a water vapor partial pressure of 28.1 mbar (21.1 torr), to a dew point of $23.0^{\circ} \mathrm{C}$, and to a relative humidity of $85 \%$.

Silica gel sorbent traps were used to sample for tritium. It is assumed that tritium produced by the waste combines with hydroxide ions to form tritiumsubstituted water. Evaporation of the tritium-substituted water would then result in airborne radioactive contamination. Silica gel sorbent traps adsorb virtually all (normal and tritium-substituted) water vapor from the sampled tank air, and are analyzed at the WHC 222-S laboratory. Radiochemical analysis of the silica gel trap indicated the total activity of the headspace to be less than $50 \mathrm{pCi} / \mathrm{L}$ (WHC 1995).

\section{X.3.4 Discussion of Inorganic Gases and Vapors}

Aside from water vapor, the most abundant waste constituents in the tank $\mathrm{C}-102$ headspace are ammonia, nitrous' oxide, and hydrogen. These have been detected in most tank headspaces sampled to date, and are usually the dominate waste species.

The relative standard deviations of the inorganic gas and vapor results given in the last column in Table $X-2$ are good. Relative standard deviations range from $1 \%$ for nitrous oxide, to $17 \%$ for nitric oxide results. The precision reported depends both on sampling parameters (e.g., sample flow rate and flow time for sorbent traps) and analytical parameters (e.g., sample preparation, dilutions, etc.), and the small relative standard deviations suggest good control was maintained both in the field and in the laboratories.

Table X-3 lists, for comparison, selected sampling data and inorganic gas and vapor concentrations measured in tanks $\mathrm{C}-101, \mathrm{C}-102$, and $\mathrm{C}-103$. The inorganic gases and vapors in these tanks are at concentrations that support the premise that tanks $C-101$ and $C-103$ breathe primarily via their cascade lines with tank C-102. To understand this, suppose that tank $C-101$ did breathe only via its cascade line to tank $\mathrm{C}-102$ (as per the ventilation configuration). Then all the air inhaled by tank $\mathrm{C}-101$ would have the composition of air in tank $\mathrm{C}-102$, so that at steady state (neglecting any losses of constituents in transit), every headspace constituent in tank $\mathrm{C}-102$ would be present in tank $\mathrm{C}-101$ at a concentration at least as high as it is in tank $\mathrm{C}-102$. Furthermore, any gases or vapors generated or released by the waste in tank $C-101$ would raise the concentration of these constituents in tank $C-101$ above the level in tank $C$ 102. As indicated in Table $X-3$, the concentrations of hydrogen, carbon dioxide, carbon monoxide, nitric oxide, and nitrous oxide are ail significantly higher in tank $\mathrm{C}-101$ than they are in $\operatorname{tank} \mathrm{C}-102$. Likewise, the 
WHC-SD-WM-ER-459 REV. 0

concentrations of these same constituents, as well as ammonia, are higher in tank $\mathrm{C}-103$ than in tank $\mathrm{C}-102$.

Amongst the inorganic analytes listed in Table $X-3$, only ammonia is at a higher concentration in tank $\mathrm{C}-102$ than it is in tank $\mathrm{C}-101$. This exceptional relationship of ammonia, if indeed tank $\mathrm{C}-101$ breathed primarily via the cascade line with tank $\mathrm{C}-102$, may be reasonable given its solubility in water. Aqueous condensate forming in the cascade line (the dewpoint of tank $\mathrm{C}-101$ is about $30{ }^{\circ} \mathrm{C}$, Huckaby 1995a) might absorb enough of the ammonia vapor in transit to tank $\mathrm{C}-101$ to cause this constituent to be lower in tank $\mathrm{C}-101$ than in tank $\mathrm{C}-102$.

Though the data from tanks $C-101, C-102$, and $C-103$ (with special allowance for ammonia in tank $C-101$ ) are consistent with the premise that tanks $C-101$ and $C$ 103 breathe primarily via their cascade 1 ines with tank $C-102$, the data do not prove that this is happening. The selected gas and vapor concentrations may be higher in tanks $C-101$ and $C-103$ than in tank $C-102$ simply because their generation rates are higher in those tanks.

\section{X.4 ORGANIC VAPORS}

Organic vapors in the tank C-102 headspace were sampled using SUMMA ${ }^{T M}$ canisters, which were analyzed by OGIST and PNL, and triple sorbent traps (TSTs), which were analyzed by ORNL. ORNL and PNL used gas chromatographs (GCs) equipped with mass spectrometer (MS) detectors to separate, identify, and quantitate the analytes. A quantitative measurement of the total organic vapor concentration by the U.S. Environmental Protection Agency (EPA) task order 12 (TO-12) method was also performed by OGIST (EPA 1988, Rasmussen 1994a). Descriptions of sample device cleaning, sample preparations, and analyses are given by Jenkins et a1. (1994a), Rasmussen (1994a), and Klinger et a1. (1995a).

SUMMA $^{T M}$ sample results should be considered to be the primary organic vapor data for tank C-102. ORNL analyses of TST samples from this and other waste tanks generally agree with, support, and augment the SUMMA ${ }^{T}$ sample results. However, because certain WHC quality assurance requirements were not satisfied by ORNL, the quality assurance assessment of ORNL by Hendrickson (1995) should be reviewed before results unique to the TST samples are used for decision making.

\section{X.4.1 Positively Identified Organic Analytes}

Positive identification of organic analytes using the methods employed by PNL and ORNL involves matching the GC retention times and MS data from a sample with that obtained from the analysis of standards. The concentration of an analyte in the sample is said to be quantitatively measured if the response of the GC/MS has been established at several known concentrations of that analyte (i.e., the GC/MS has been calibrated for that analyte), and the MS response to 
WHC-SD-WM-ER-459 REV. 0

the analyte in the sample is between the lowest and highest responses to the known concentrations (i.e., the analyte is within the calibration range).

ORNL and PNL were assigned different lists of organic compounds, or target analytes, to positively identify and measure quantitatively. The ORNL target analyte list was derived from a review of the tank $\mathrm{C}-103$ headspace constituents by a panel of toxicology experts (Mahlum et al. 1994). The PNL target analyte list included 39 compounds of the EPA task order 14 (TO-14) method, which are primarily halocarbons and common industrial solvents (EPA 1988), plus 14 analytes selected mainly from the toxicology panel's review of tank C-103.

Table $X-4$ lists the organic compounds positively identified and quantitated in SUMMA $^{T M}$ samples. Analysis for methane was performed by OGIST (Rasmussen 1994a), other SUMMA analyses were performed according to the EPA TO-14 methodology by PNL (EPA 1988, Klinger et a7. 1995a). Only 2 of the 39 TO-14 target analytes (i.e., toluene and trichlorofluoromethane), but all 14 of the additional target analytes were above the 0.005 ppmv quantitation limit of the analyses. Averages reported are from analyses of 3 SUMMA ${ }^{\text {TM }}$ canister samples.

Jenkins et al. (1994a) report the positive identification of 26 of 27 target analytes in TST samples. 1,1-Dichloroethene was the only TST target analyte not detected in the TST samples. The average concentrations of the target analytes, from the analysis of 3 TSTs, are given in Table $X-5$.

The concentrations of tributyl phosphate and dibutyl butylphosphonate reported in Table X-5 probably underestimate the actual concentrations in the tank headspace. These compounds have very low volatility, and are thought to be adsorbed by glass fiber filters used during sampling to protect samples from radiolytic particulates.

Both PNL and ORNL report target analyte concentrations in ppmv of analyte in dry air. To correct for the measured water vapor content of tank C-102 and obtain concentration in ppmv of analyte in moist tank air, multiply the dryair ppmv concentrations by 0.972 .

Eleven target analytes were common to both TST and SUMMA ${ }^{\text {TM }}$ analyses. Table X6 lists these, and their reported average concentrations in TST and SUMMA ${ }^{\text {TM }}$ samples. Results from these 2 sampling and analytical methods are in good agreement for the nitriles (acetonitrile, propanenitrile, and butanenitrile). The methods also agree reasonably well on the concentrations of acetone, $n-$ heptane, and $n$-decane. However, as indicated in Table $X-6$, the reported concentrations of dichloromethane, benzene, toluene, and $n$-hexane by the 2 methods are not in agreement. The differences in reported values are not significant except for benzene. Benzene, which is reported to be at $0.32 \mathrm{ppmv}$ in TST samples and < 0.005 ppmv in SUMMA ${ }^{\text {IM }}$ samples, has an 8-hr NIOSH REL of $0.1 \mathrm{ppmv}$. Despite the relatively poor precision of the TST benzene measurements, it is advisable to assume (to be conservative) the higher benzene concentration of $0.32 \mathrm{ppmv}$ is correct. 
WHC-SD-WM-ER-459 REV. 0

The most abundant analytes in Tables $X-4$ and $X-5$ are methane, acetone, $n-$ dodecane, acetonitrile, n-tridecane, 1-butanol, and n-undecane. At the reported concentrations, the target analytes do not individually or collectively represent a flammability hazard.

\section{X.4.2 Tentatively Identified Organic Analytes}

In addition to the target analytes, the ORNL and PNL analytical procedures allow the tentative identification of other organic compounds. Tentative identification of analytes was performed by comparing the MS molecular fragmentation patterns with a library of known MS fragmentation patterns. This method allows an organic analyte to be identified (with reasonable certainty) as an alkane, a ketone, an aldehyde, etc., and may also determine its molecular weight. The method usually does not, however, allow the unambiguous identification of structural isomers, and this ambiguity increases with analyte molecular weight. Many analytes can be tentatively identified with reasonable confidence without having to inject standards of each into the GC/MS to determine their GC retention times or specific MS patterns.

By the nature of the sampling devices, virtually all organic vapors present in the tank headspace are collected by both TST and SUMMA ${ }^{\text {TM }}$ samples. Analyses of the samples are designed to recover, separate, identify, and quantify the organic vapors in the samples. TSTs are not good for collecting highly volatile compounds (i.e., molecules more volatile than propane), but are quite good for most others. In contrast, the recovery of very low volatility compounds (i.e., molecules with more than about 15 carbon atoms) and some polar compounds with moderate volatility (i.e., butanal) from SUMMA ${ }^{\text {TM }}$ samples has been problematic.

The list of tentatively identified compounds recovered from SUMMA ${ }^{T M}$ samples, with estimated concentrations, is given in Table $X-7$. Compounds are listed in Table $X-7$ in the order by which they eluted chromatographically, and only nonzero results are included in the reported averages. The list of tentatively identified compounds detected in TST samples, and their estimated concentrations, is given in Table X-8. Compounds are also listed in Table X-8 according to the order by which the eluted chromatographically. The averages reported by ORNL in Table X-8 are all 3-sample averages, and if an analyte was not detected in a sample, its concentration in that sample was considered to be zero for averaging purposes. Estimated concentrations are in $\mathrm{mg} / \mathrm{m}^{3}$, based on dry air at $0^{\circ} \mathrm{C}$ and 1.01 bar.

The ORNL and PNL methods used to tentatively identify and estimate concentrations are described by Jenkins et al. (1994a) and K1inger et al. (1995a), respectively, and should be reviewed before this data is used for decision making. Concentrations given in Tables $X-7$ and $X-8$ should be considered rough estimates. Results in Tables $X-7$ and $X-8$ are presented in terms of observed chromatographic peaks, and are not adjusted for the occurrence of split peaks (e.g., Cmpd \# 123 and 124 in Table X-8) or the assignment of the same identity to different peaks (e.g., Cmpd \# 105 and 113 in Table $\mathrm{X}-8$ ). In these instances, the estimated concentration of a compound 
WHC-SD-WM-ER-459 REV, 0

appearing in more than 1 peak is simply the sum of the individual peak estimates.

\section{X.4.3 Total Nonmethane Organic Compounds}

OGIST measured the total nonmethane organic compound (TNMOC) concentration in 3 SUMMA $^{\text {TM }}$ canister samples using the EPA TO-12 method (Rasmussen 1994a). The sample mean was $313 \mathrm{mg} / \mathrm{m}^{3}$, with a standard deviation of about $5 \mathrm{mg} / \mathrm{m}^{3}$. Though data on other tanks is limited, this value is much higher than typical for the waste tanks sampled to date.

A comparable analysis of 1 TST sample by gas chromatography with flame ionization detection indicated the organic vapor concentration to be $296 \mathrm{mg} / \mathrm{m}^{3}$ (Jenkins et al. 1994a). This is in excellent agreement with the EPA T0-12 result. EPA TO-12 method TNMOC measurements of other waste tanks have ranged from as high as $5,000 \mathrm{mg} / \mathrm{m}^{3}$ in tank C-103 (Rasmussen and Einfeld 1994), to as low as $0.18 \mathrm{mg} / \mathrm{m}^{3}$ in tank C-111 (Rasmussen 1994b), while the TNMOC concentration of clean ambient air ranges from about 0.03 to $0.1 \mathrm{mg} / \mathrm{m}^{3}$.

\section{X.4.4 Discussion of Organic Analytes}

It is useful to consider the organic vapors in the waste tanks in terms of their sources. Some organic compounds, particularly semivolatile compounds, were constituents of the waste sent to the tank farms, and are present in the tank headspaces because they are still evaporating from the wastes. 0ther organic compounds present in the tanks have been produced via chemical and radiolytic reactions of the original organic wastes. The most abundant of these degradation products in tank headspaces are volatile, and most contain functional groups.

Tank C-102 is known to have contained bulk quantities of a semivolatile organic liquid (Carothers 1988), and its presence is still evident in auger samples (Campbell et al. 1995). The high vapor concentrations of the semivolatile normal paraffinic hydrocarbons (NPHs), are understandable given their presence in the waste. In fact, the NPH vapor concentrations are perhaps lower than would be expected if tank C-103 were ventilated (as intended) via the cascade line to tank C-102. For example, ORNL measured the $n$-dodecane and $n$-tridecane vapor concentrations to be about 40 and $52 \mathrm{ppmv}$, respectively, in tank $\mathrm{C}-103$, and only about 0.91 and $0.81 \mathrm{ppmv}$, respectively, in tank C-102.

The organic vapor distributions in tanks $C-102$ and $C-103$ are graphically illustrated in Figures $X-1$ and $X-2$. A total ion chromatogram for a SUMMA ${ }^{T M}$ sample from tank C-102 is displayed in the upper half of both figures (the same chromatogram appears in both figures). In the lower halves of the figures, a similar total ion chromatogram for a SUMMA ${ }^{\text {TM }}$ sample from tank C-103 is displayed. In Figure $X-1$, the ordinate scale of the tank $C-103$ (lower) chromatogram has been adjusted to reveal detail comparable to that given in the tank C-102 (upper) chromatogram. Note, however, that in Figure $X-1$ the tallest peaks of the tank $C-103$ (lower) chromatogram (i.e., at 44 and 48 


\section{WHC-SD-WM-ER-459 REV. 0}

minutes) are off-scale, and are truncated. In Figure $X-2$, the ordinate scale of the tank $\mathrm{C}-103$ (lower) chromatogram has been adjusted so that these tallest peaks are not off-scale.

In Figures $X-1$ and $X-2$, the abscissa of the chromatograms is elution time, and the ordinate is instrumental response. The mixture of organic compounds in each sample has been separated chromatographically so that, inasmuch as the separation is complete, individual analytes elute at different times and appear as individual peaks. Each peak height is roughly proportional to the concentration of the associated analyte present in the sample. Rough comparisons of the concentrations of compounds in tanks C-102 and C-103 can be made by considering that the acetone peak, appearing as a relatively tall peak at about 9 min in both chromatograms of Figure $X-1$, is about 3.8 ppmv in the tank C-102 sample, and about 19.3 ppmv in the tank C-103 sample (Huckaby and Story 1994).

The tallest peak in the tank C-102 (upper) chromatogram of Figure 1, at about $18 \mathrm{~min}$, is due to 1-butanol. The 5 next tallest peaks in the tank C-102 chromatogram are $n$-decane (at $36 \mathrm{~min}$ ), n-undecane (at $40 \mathrm{~min}$ ), n-dodecane (at $44 \mathrm{~min}$ ), n-tridecane (at $48 \mathrm{~min}$ ), and $n$-tetradecane (at $52 \mathrm{~min}$ ). These are the semivolatile NPHs. Generally, the more volatile a compound is, the faster it elutes through the GC, so the volatile compounds are to the left in the chromatograms, and the semivolatile compounds are to the right.

Examination of Figures $\mathrm{X}-1$ and $\mathrm{X}-2$ indicates many similarities between the organic vapor distributions of tanks $\mathrm{C}-102$ and $\mathrm{C}-103$. Of particular interest are the peaks scattered amongst the NPH peaks between about 40 and 52 min in both chromatograms in Figure X-2. These peaks are from semivolatile organic compounds, and are thought to be impurities of the NPH PUREX process diluent. The locations and relative heights of these peaks in the 2 chromatograms are so similar that either the semivolatile paraffinic liquids in tanks C-102 and C-103 came from the same batch of PUREX process diluent, and/or these headspace constituents are being transported via the cascade line from tank C103 to tank C-102. Waste transfer history does suggest that the organic liquid currently present in tank C-103 may have come from tank C-102 (Carothers 1988).

The relationship between the organic vapors in tanks $C-102$ and $C-101$ has been examined by Huckaby (1995a). A visual comparison of the organic vapor distributions in tanks $\mathrm{C}-102$ and $\mathrm{C}-101$ is provided in Figure $\mathrm{X}-3$ (Klinger et al. 1995a, Lucke et al. 1995b). The ordinate scales in these 2 chromatograms are different, as are the amounts of sample analyzed, but the peak height-toconcentration relationships are similar. Specifically, the tallest peak in the tank C-101 (lower) chromatogram, at about $44 \mathrm{~min}$, has an estimated concentration of $15.2 \mathrm{mg} / \mathrm{m}^{3}$, while the corresponding peak in the tank C-102 (upper) chromatogram (also at about $44 \mathrm{~min}$ ), has an estimated concentration of $13.5 \mathrm{mg} / \mathrm{m}^{3}$.

Comparison of the chromatograms in Figure $X-3$ suggests that tank $C-101$ has its own supply of semivolatile organic waste, and that the cascade line between 
WHC-SD-WM-ER-459 REV. 0

them does not allow significant transfer of semivolatile organic vapors from tank C-101 to tank C-102. Specifically, the non-NPH semivolatile paraffinic compounds present in tank $\mathrm{C}-102$ are at relatively low concentrations and appear we1]-separated in the tank $\mathrm{C}-102$ (upper) chromatogram in Figure $\mathrm{X}-3$. By contrast, the concentrations of compounds eluting between $n$-undecane (at 40 min) and n-tetradecane (at $52 \mathrm{~min}$ ) in the tank C-101 chromatogram are so much higher that they are no longer separated by the GC. The major analytes in this region were tentatively identified as branched alkanes, cyclic alkanes, and alkenes (Huckaby 1995a). Careful examination of the locations and relative heights of these non-NPH compound peaks suggests that there are strong similarities between the organic wastes, and that tank $\mathrm{C}-101$ may have stored the same organic liquid waste as tanks $\mathrm{C}-102$ and $\mathrm{C}-103$.

TST sample chromatograms from tanks C-101, C-102, and C-103 are similar in character to the SUMMA ${ }^{\mathrm{TM}}$ sample chromatograms (Jenkins et al. 1994b, 1994a, 1994c). Like the chromatograms shown in Figures $X-1$ and $X-3$, the TST

chromatograms indicate that tank $C-101$ has a much higher concentration of nonNPH semivolatile organic vapors than does tank $\mathrm{C}-102$.

Given the apparent semivolatile organic waste similarities, it is not clear whether tank $\mathrm{C}-103$ was breathing, as intended, via the cascade line with tank C-102 when their headspaces were sampled. Likewise, the data does not clearly indicate whether or not tank $C-101$ is breathing via its cascade line with tank $C-102$. However, the data do indicate that the cascade lines between tanks $C$ 102 and $\mathrm{C}-103$, and between tanks $\mathrm{C}-102$ and $\mathrm{C}-101$ do not transport significant amounts of the semivolatile organic vapors.

The volatile constituents identified in the SUMMA ${ }^{\text {TM }}$ and TST samples from tank C-102 are generally thought to be chemical and radiolytic reaction products of the semivolatile organic compounds. Supporting this is the fact that several compounds of each homologous series are commonly found in this as well as other waste tanks. Specifically, the following homologous series of straightchain compounds were identified in tank C-102 samples:

- 2-ketones, from 2-propanone (acetone) through 2-nonanone;

- aldehydes, including acetaldehyde (ethanal), from butanal through octanal;

- nitriles, from acetonitrile (ethanenitrile) through octanenitrile;

- alkanes, including methane, from propane through nonane; and

- 1-alkenes, from propene through 1-octene.

Similarities between the volatile organic compounds in tanks $C-101, C-102$, and $C-103$ are evident in Figures $X-1$ and $X-3$. Many peaks are common to the chromatograms of all 3 tanks, and many have similar relative peak heights. However, transport of these vapors from either tanks C-101 or C-103 would not completely account for the volatile compounds in tank $\mathrm{C}-102$. The 


\section{WHC-SD-WM-ER-459 REV. 0}

concentration of 1-butanol, for example, is much more prominent amongst the volatile constituents in tank $\mathrm{C}-102$ than it is in either tanks $\mathrm{C}-101$ or $\mathrm{C}-103$. Furthermore, because the volatile organic vapors are thought to be produced by the degradation of the semivolatile organics (which appear to be very similar in tanks $\mathrm{C}-102$ and $\mathrm{C}-103)$, the types and relative concentrations of volatile organic compounds in these tanks would be expected to be very similar, even if the cascade lines between them allowed no transport of vapors. 
WHC-SD-WM-ER-459 REV. 0

Table X-1

Tank C-102 Gas and Vapor Sample Type and Number

\begin{tabular}{|c|c|c|c|c|}
\hline Laboratory & Sampling Device & $\begin{array}{c}\text { Nominal Sample } \\
\text { Volume }(\mathrm{L}) \\
\end{array}$ & Target Analytes & Number of Samples \\
\hline $\begin{array}{l}\text { Oak Ridge National } \\
\text { Laboratories }\end{array}$ & Triple Sorbent Trap & $\begin{array}{l}0.1 \text { and } \\
0.5\end{array}$ & Organic vapors & $\begin{array}{l}8 \text { tank air samples, } \\
+2 \text { trip blanks } \\
+2 \text { field blanks } \\
\end{array}$ \\
\hline $\begin{array}{l}\text { Oregon Graduate } \\
\text { Institute of Science } \\
\text { and Technology }\end{array}$ & SUMMA ${ }^{T M}$ canister & 6.0 & $\begin{array}{l}\text { Hydrogen, } \\
\text { Nitrous Oxide, } \\
\text { Carbon Dioxide, } \\
\text { Carbon Monoxide, } \\
\text { Methane, TNMOC }\end{array}$ & 3 tank air samples \\
\hline \multirow[t]{5}{*}{$\begin{array}{l}\text { Pacific Northwest } \\
\text { Laboratories }\end{array}$} & $\begin{array}{l}\text { Acidified Carbon } \\
\text { Sorbent Trap }\end{array}$ & 3.0 & Ammonia & $\begin{array}{l}6 \text { tank air samples } \\
+3 \text { trip blank }\end{array}$ \\
\hline & $\begin{array}{l}\text { Triethanolamine } \\
\text { Sorbent Trap }\end{array}$ & 3.0 & Nitrogen Dioxide & $\begin{array}{l}6 \text { tank air samples } \\
+3 \text { trip blank }\end{array}$ \\
\hline & $\begin{array}{l}\text { Oxidation Bed }+ \\
\text { Triethanolamine } \\
\text { Sorbent Trap }\end{array}$ & 3.0 & Nitric Oxide & $\begin{array}{l}6 \text { tank air samples } \\
+3 \text { trip blank }\end{array}$ \\
\hline & $\begin{array}{l}\text { Silica Gel Sorbent } \\
\text { Trap }\end{array}$ & 3.0 & Water vapor & $\begin{array}{l}6 \text { tank air samples } \\
+3 \text { trip blanks }\end{array}$ \\
\hline & SUMMA ${ }^{T M}$ canister & 6.0 & Organic vapors & $\begin{array}{l}3 \text { tank air samples + } \\
2 \text { ambient air samples }\end{array}$ \\
\hline WHC 222-S Laboratory & $\begin{array}{l}\text { Silica Gel Sorbent } \\
\text { Trap }\end{array}$ & 1.0 & $\begin{array}{l}\text { Tritium-Substituted } \\
\text { Water Vapor } \\
\end{array}$ & 1 tank air sample \\
\hline
\end{tabular}

1. $T$ TMOC $=$ total nonmethane organic compound $[s]$. 
WHC-SD-WM-ER-459 REV. 0

Table X-2

Tank C-102 Inorganic Gas and Vapor Concentrations

\begin{tabular}{|c|c|c|c|c|c|c|}
\hline Compound & $\mathrm{CAS}^{2}$ number & $\begin{array}{l}\text { Sample } \\
\text { Type }\end{array}$ & $\begin{array}{c}\text { Number } \\
\text { of } \\
\text { samples } \\
\end{array}$ & $\begin{array}{c}\text { Average } \\
\text { (ppmv) }\end{array}$ & $\begin{array}{c}\text { Standard } \\
\text { Deviation } \\
\text { (ppmv) }\end{array}$ & $\begin{array}{l}\mathrm{RSD}^{3} \\
(\%)\end{array}$ \\
\hline Ammonia, $\mathrm{NH}_{3}$ & $7664-41-7$ & Sorbent Trap & 6 & 189 & 3 & 1.6 \\
\hline Carbon Dioxide, $\mathrm{CO}_{2}$ & $124-38-9$ & SUMMA $^{\text {TM }}$ & 3 & 8.2 & 0.36 & 4 \\
\hline Carbon Monoxide, CO & $630-08-0$ & SUMMA $^{\top M}$ & 3 & 4.0 & 0.64 & 16 \\
\hline Hydrogen, $\mathrm{H}_{2}$ & $1333-74-0$ & SUMMA $^{T M}$ & 3 & 133 & 2.64 & 2 \\
\hline Nitric Oxide, No & $10102-43-9$ & Sorbent Trap & $\dot{6}$ & 0.24 & 0.04 & 17 \\
\hline Nitrogen Dioxide, $\mathrm{NO}_{2}$ & $10102-44-0$ & Sorbent Trap & 6 & $\leq 0.05$ & -- & -- \\
\hline Nitrous Oxide, $\mathrm{N}_{2} \mathrm{O}$ & $10024-97-2$ & SUMMA $^{T M}$ & 3 & 154 & 1.53 & 1 \\
\hline Water Vapor, $\mathrm{H}_{2} \mathrm{O}$ & $7732-18-5$ & Sorbent Trap & 6 & $\begin{array}{l}28,400 \\
(20.4 \mathrm{mg} / \mathrm{L})\end{array}$ & $\begin{array}{r}1,500 \\
(1.1 \mathrm{mg} / \mathrm{L})\end{array}$ & 5 \\
\hline
\end{tabular}

2. CAS $=$ Chemical Abstracts Service.

3. $R S D=$ relative standard deviation. 
WHC-SD-WM-ER-459 REV. 0

Table $X-3$

Comparison of Tank C-101, C-102, and C-103 Headspace Constituents ${ }^{1}$

\begin{tabular}{lccc}
\hline \hline Tank: & $\mathrm{C}-101$ & $\mathrm{C}-102^{2}$ & $\mathrm{C}-103^{3}$ \\
\hline \hline Date sampled, (mo/day/yr) & $9 / 1 / 94$ & $8 / 23 / 94$ & $\begin{array}{c}4 / 7 / 94- \\
5 / 25 / 94\end{array}$ \\
\hline Headspace temperature, ( ${ }^{\circ} \mathrm{C}$ ) & 34 & 25.8 & 38 \\
\hline Ammonia, (ppmv) & 98 & 189 & 304 \\
Hydrogen, (ppmv) & 436 & 133 & 782 \\
Carbon dioxide, (ppmv) & 1426 & 8.2 & -- \\
Carbon monoxide, (ppmv) & 15.5 & 4.0 & 26.7 \\
Nitric oxide, (ppmv) & 1.5 & 0.24 & 1.5 \\
Nitrogen dioxide, (ppmv) & 0.04 & 50.05 & 50.04 \\
Nitrous oxide, (ppmv) & 642 & 154 & 763 \\
Water vapor, (mg/m ${ }^{3}$ ) & 30.1 & 20.4 & 42.2 \\
Water vapor, (\% relative humidity) & 80 & 85 & 91 \\
\hline Ethanenitrile (acetonitrile), (ppmv) & 0.69 & 0.34 & 9.1 \\
Propanone (acetone), (ppmv) & 1.0 & 2.2 & 8.8 \\
1-Butanol, (ppmv) & 0.46 & 7.6 & 28.4 \\
n-Dodecane, (ppmv) & 0.94 & 0.91 & 40.3 \\
n-Tridecane, (ppmv) & 0.61 & 0.81 & 52.0 \\
\hline Total nonmethane organic compounds, & 256 & 313 & 3,000 \\
(mg/m & & & $5,000^{4}$ \\
\hline \hline
\end{tabular}

1. For consistency in this table, individual organic analyte results are all from TST samples.

2. Data are from Huckaby 1995a.

3. Tank C-103 was sampled on various dates; data are from Huckaby and Story 1994.

4. TNMOC concentrations were too high for precise measurement; this range is from Rasmussen and Einfeld 1994. 
WHC-SD-WM-ER-459 REV. 0

Table X-4

Tank C-102 Positively Identified Compounds in SUMMA ${ }^{\text {TM }}$ Samples

\begin{tabular}{clcccc}
\hline $\begin{array}{c}\text { Cmpd } \\
\#\end{array}$ & Compound & $\begin{array}{c}\text { CAS }^{1} \\
\text { Number }\end{array}$ & $\begin{array}{c}\text { Average } \\
\text { (ppmv) }\end{array}$ & $\begin{array}{c}\text { Standard } \\
\text { Deviation } \\
\text { (ppmv) }\end{array}$ & $\begin{array}{c}\text { RSD }^{2} \\
(\%)\end{array}$ \\
\hline 1 & Methane & & & \\
2 & Ethanenitrile & $75-82-8$ & 4.9 & 0.06 & 1.2 \\
& (acetonitrile) & & 0.33 & 0.04 & 12 \\
3 & Propanone (acetone) & $67-64-1$ & 3.18 & 0.54 & 17 \\
4 & Trichlorofluoromethane & $75-69-4$ & 0.051 & 0.008 & 16 \\
5 & Propanenitrile & $107-12-0$ & 0.058 & 0.0004 & 0.7 \\
6 & Propanol & $71-23-8$ & 0.21 & 0.003 & 1.2 \\
7 & 2-Butanone & $78-93-3$ & 0.72 & 0.013 & 1.8 \\
8 & n-Hexane & $110-54-3$ & 1.62 & 0.029 & 1.8 \\
9 & Tetrahydrofuran & $109-99-9$ & 0.28 & 0.005 & 1.7 \\
10 & Butanenitrile & $109-74-0$ & 0.083 & 0.002 & 2.5 \\
11 & Cyclohexane & $110-82-7$ & 0.031 & 0.002 & 6 \\
12 & n-Heptane & $142-82-5$ & 0.20 & 0.005 & 2.4 \\
13 & 4-Methyl-2-Pentanone & $108-10-1$ & 0.046 & 0.003 & 6 \\
14 & Pyridine & $110-86-1$ & 0.019 & 0.001 & 5 \\
15 & Toluene & $108-88-3$ & 0.006 & 0.0004 & 7 \\
16 & Cyclohexanone & $108-94-1$ & 0.015 & 0.0008 & 5 \\
17 & n-Decane & $124-18-5$ & 0.64 & 0.042 & 6 \\
\hline \hline Sum of positively identified compounds: & & $\mathrm{mg} / \mathrm{m}^{3}$ & \\
\hline \hline
\end{tabular}

1. CAS = Chemical Abstract Service.

2. $R S D=$ relative standard deviation .

3. Methane results are from Rasmussen 1994a, all others are from Klinger et a1. 1995a. 
WHC-SD-WM-ER-459 REV. 0

Table X-5

Tank C-102 Positively Identified Organic Compounds in TST Samples

\begin{tabular}{|c|c|c|c|c|c|}
\hline Cmpd & Compound & $\begin{array}{l}\text { CAS }^{1} \\
\text { Number }\end{array}$ & $\begin{array}{l}\text { Average } \\
\text { (ppmv) }\end{array}$ & $\begin{array}{c}\text { Standard } \\
\text { Deviation } \\
\text { (ppmv) }\end{array}$ & $\begin{array}{r}\mathrm{RSD}^{2} \\
(\%)\end{array}$ \\
\hline 1 & $\begin{array}{l}\text { Ethanenitrile } \\
\text { (acetonitrile) }\end{array}$ & $75-05-8$ & 0.34 & 0.04 & 11 \\
\hline 2 & Propanone $^{3}$ (acetone) & $67-64-1$ & 2.2 & 0.5 & 22 \\
\hline 3 & $\begin{array}{l}\text { Dichloromethane } \\
\text { (methylene chloride) }\end{array}$ & $75-09-2$ & 0.043 & 0.045 & 104 \\
\hline 4 & Propanenitrile $e^{3}$ & $107-12-0$ & 0.043 & 0.001 & 3 \\
\hline 5 & Butanal ${ }^{3}$ & $123-72-8$ & 2.6 & 1.7 & 64 \\
\hline 6 & n-Hexane ${ }^{3}$ & $110-54-3$ & 0.097 & 0.008 & 8 \\
\hline 7 & Benzene & $71-43-2$ & 0.32 & 0.31 & 98 \\
\hline 8 & 1-Butano $1^{3}$ & $71-36-3$ & 7.6 & 1.7 & 22 \\
\hline 9 & Butanenitrile & $109-74-0$ & 0.061 & 0.005 & 9 \\
\hline 10 & 2-Pentanone & $107-87-9$ & 0.15 & 0.02 & 16 \\
\hline 11 & n-Heptane & $142-82-5$ & 0.085 & 0.012 & 15 \\
\hline 12 & Toluene $^{3}$ & $108-88-3$ & 0.082 & 0.072 & 88 \\
\hline 13 & Pentanenitrile $\mathrm{e}^{3}$ & $110-59-8$ & 0.030 & 0.001 & 5 \\
\hline 14 & 2-Hexanone & $591-78-6$ & 0.072 & 0.009 & 12 \\
\hline 15 & n-Octane & $111-65-9$ & 0.071 & 0.008 & 11 \\
\hline 16 & Hexanenitrile & $628-73-9$ & 0.030 & 0.001 & 4 \\
\hline 17 & 2-Heptanone & $110-43-0$ & 0.079 & 0.024 & 31 \\
\hline 18 & $n$-Nonane & $111-84-2$ & 0.069 & 0.005 & 8 \\
\hline 19 & Heptanenitrile & $629-08-3$ & 0.032 & 0.005 & 15 \\
\hline 20 & 2-0ctanone ${ }^{3}$ & $111-13-7$ & 0.043 & 0.019 & 44 \\
\hline 21 & n-Decane & $124-18-5$ & 0.27 & 0.05 & 18 \\
\hline 22 & $n$-Undecane ${ }^{3}$ & $1120-21-4$ & 0.70 & 0.13 & 19 \\
\hline 23 & n-Dodecane ${ }^{3}$ & $112-40-3$ & 0.91 & 0.10 & 11 \\
\hline 24 & n-Tridecane ${ }^{3}$ & $629-50-5$ & 0.81 & 0.15 & 19 \\
\hline 25 & Dibutyl butylphosphonate ${ }_{3}$ & $78-46-6$ & 0.0050 & 0.0012 & .24 \\
\hline 26 & Tributyl phosphate ${ }^{3}$ & $126-73-8$ & 0.075 & 0.007 & 10 \\
\hline
\end{tabular}


WHC-SD-WM-ER-459 REV. 0

Sum of positively identified compounds: $\quad 65.5 \mathrm{mg} / \mathrm{m}^{3}$

1. CAS = Chemical Abstract Service.

2. $R S D=$ relative standard deviation .

3. Two or more samples were outside calibration range. 
WHC-SD-WM-ER-459 REV. 0

Table X-6

Tank C-102 Comparison of Organic Compounds in TST and SUMMA ${ }^{\text {TM }}$ Samples

\begin{tabular}{lccc}
\hline Compound & $\begin{array}{c}\text { CAS }^{1} \\
\text { Number }\end{array}$ & $\begin{array}{c}\text { TST } \\
\text { Average } \\
\text { (ppmv) }\end{array}$ & $\begin{array}{c}\text { SUMMA } \\
\text { Average } \\
\text { (ppmv) }\end{array}$ \\
\hline 1,1-Dichloroethene (vinylidene chloride) & $75-35-4$ & $<0.00092$ & $<0.005$ \\
Dichloromethane (methylene chloride) & $75-09-2$ & 0.043 & $<0.005$ \\
Propanone (acetone) & $67-64-1$ & 2.2 & 3.18 \\
Ethanenitrile (acetonitrile) & $75-05-8$ & 0.34 & 0.33 \\
Propanenitrile & $107-12-0$ & 0.043 & 0.058 \\
Butanenitrile & $109-74-0$ & 0.061 & 0.083 \\
Benzene & $71-43-2$ & 0.32 & $<0.005$ \\
Toluene & $108-88-3$ & 0.082 & 0.006 \\
n-Hexane & $110-54-3$ & 0.097 & 1.62 \\
n-Heptane & $142-82-5$ & 0.085 & 0.20 \\
n-Decane & $124-18-5$ & 0.27 & 0.64 \\
\hline \hline
\end{tabular}

1. CAS = Chemical Abstract Service. 
WHC-SD-WM-ER-459 REV. 0

Table X-7

Tank C-102 Tentatively Identified Compounds in SUMMA ${ }^{\text {TM }}$ Samples

\begin{tabular}{|c|c|c|c|c|}
\hline$\underset{\#}{C \operatorname{mpd}}$ & Compound & $\begin{array}{c}\text { CAS }^{1} \\
\text { Number }\end{array}$ & $\begin{array}{c}\text { Average } \\
\left(\mathrm{mg} / \mathrm{m}^{3}\right)\end{array}$ & $\begin{array}{c}\text { Standard } \\
\text { Deviation } \\
\left(\mathrm{mg} / \mathrm{m}^{3}\right)\end{array}$ \\
\hline 1 & Propene & $115-07-1$ & 1.36 & 0.05 \\
\hline 2 & Propane & $74-98-6$ & 0.64 & 0.02 \\
\hline 3 & 1-Propyne & $74-99-7$ & 0.60 & 0.02 \\
\hline 4 & Cyclopropane & $75-19-4$ & 0.25 & 0.01 \\
\hline 5 & Ethanal (acetaldehyde) & $75-07-0$ & 0.68 & 0.13 \\
\hline 6 & Methanol (methyl alcohol) & $67-56-1$ & $<0.01$ & -- \\
\hline 7 & 1-Butene & $106-98-9$ & 0.61 & 0.09 \\
\hline 8 & n-Butane & $106-97-8$ & 1.09 & 0.37 \\
\hline 9 & 1-Propene, 2-methyl- & $115-11-7$ & 0.12 & 0.02 \\
\hline 10 & Ethanol & $64-17-5$ & 0.16 & 0.02 \\
\hline 11 & 1-Pentene & $109-67-1$ & 0.30 & 0.05 \\
\hline 12 & n-Pentane & $109-66-0$ & 0.62 & 0.10 \\
\hline 13 & 2-Pentanone & $107-87-9$ & $<0.04$ & -- \\
\hline 14 & 2-Pentene & $109-68-2$ & $<0.03$ & -- \\
\hline 15 & Pentane, 2-methyl- & $107-83-5$ & 0.22 & 0.004 \\
\hline 16 & Butanal & $123-72-8$ & 0.77 & 0.03 \\
\hline 17 & 1-Hexene & $592-41-6$ & 0.35 & 0.01 \\
\hline 18 & Nitric acid, ethyl ester & $625-58-1$ & 0.18 & 0.01 \\
\hline 19 & Nitrous acid, butyl ester ${ }^{3}$ & $544-16-1$ & 0.09 & -- \\
\hline 20 & 3-Buten-1-o ${ }^{3}$ & $627-27-0$ & 0.08 & -- \\
\hline 21 & Butanal, 3-methyl-3 & $590-86-3$ & 0.08 & -- \\
\hline 22 & 2-Butanone, 3-methy1- & $563-80-4$ & 0.13 & 0.003 \\
\hline 23 & 1-Butanol & $71-36-3$ & 27.82 & 3.56 \\
\hline 24 & Nitric acid, 1-methylethyl ester & $1712-64-7$ & 0.15 & 0.01 \\
\hline 25 & 2-Pentanone & $107-87-9$ & 1.61 & 0.03 \\
\hline 26 & Pentana 1 & $110-62-3$ & 0.90 & 0.01 \\
\hline 27 & 1-Heptene & $592-76-7$ & 0.34 & 0.002 \\
\hline
\end{tabular}


WHC-SD-WM-ER-459 REV. 0

\begin{tabular}{|c|c|c|c|c|}
\hline$\underset{\#}{C m p d}$ & Compound & $\begin{array}{l}\text { CAS }^{1} \\
\text { Number }\end{array}$ & $\begin{array}{c}\text { Average } \\
\left(\mathrm{mg} / \mathrm{m}^{3}\right)\end{array}$ & $\begin{array}{c}\text { Standard }{ }^{2} \\
\text { Deviation } \\
\left(\mathrm{mg} / \mathrm{m}^{3}\right)\end{array}$ \\
\hline 28 & 2-Pentanone, 3-methy $1-$ & $565-61-7$ & 0.083 & 0.002 \\
\hline 29 & Pentanenitrile & $110-59-8$ & 0.16 & 0.001 \\
\hline 30 & 1-Heptanol & $53535-33-4$ & 0.30 & 0.01 \\
\hline 31 & Unknown Alkyl Nitrate & & 0.083 & 0.004 \\
\hline 32 & Heptane, 2-methy1- & $592-27-8$ & 0.24 & 0.01 \\
\hline 33 & 2-Hexanone & $591-78-6$ & 0.73 & 0.01 \\
\hline 34 & Hexanal & $66-25-1$ & 0.50 & 0.02 \\
\hline 35 & 1-Octene & $111-66-0$ & 0.23 & 0.01 \\
\hline 36 & n-0ctane & $111-65-9$ & 1.22 & 0.03 \\
\hline 37 & 2-Hexanone, 5-methy1- & $110-12-3$ & 0.19 & 0.01 \\
\hline 38 & Hexanenitrile & $628-73-9$ & 0.14 & 0.003 \\
\hline 39 & 2-Furanmethanol, tetrahydro- ${ }^{4}$ & $97-99-4$ & 0.074 & 0.01 \\
\hline 40 & 2-Heptanone & $110-43-0$ & 0.86 & 0.06 \\
\hline 41 & Heptanal & $111-71-7$ & 0.39 & 0.01 \\
\hline 42 & n-Nonane & $111-84-2$ & 0.87 & 0.02 \\
\hline 43 & Nitric acid, pentyl ester & $1002-16-0$ & 0.16 & 0.01 \\
\hline 44 & 2-Heptanone, 4-methy1- & $6137-06-0$ & 0.082 & 0.002 \\
\hline 45 & 2-Heptanone, 6-methy1- & $928-68-7$ & 1.25 & 0.02 \\
\hline 46 & Cyclohexane, propyl- & $1678-92-8$ & 0.11 & 0.004 \\
\hline 47 & Heptanenitrile & $629-08-3$ & 0.41 & 0.02 \\
\hline 48 & 4-0ctanone & $589-63-9$ & 0.11 & 0.004 \\
\hline 49 & Unknown C10 Alkane & & 0.17 & 0.01 \\
\hline 50 & Unknown C10 Alkane & & 0.16 & 0.01 \\
\hline 51 & Unknown Alkane ${ }^{3}$ & & 0.15 & -- \\
\hline 52 & 2-0ctanone & $111-13-7$ & 0.66 & 0.01 \\
\hline 53 & Cyclohexane, 1,1,2,3-tetramethyl- & $6783-92-2$ & 0.20 & 0.003 \\
\hline 54 & Octanal & $124-13-0$ & 0.25 & 0.03 \\
\hline 55 & Unknown C9 Alkene/Cycloalkane & & 0.21 & 0.003 \\
\hline
\end{tabular}


WHC-SD-WM-ER-459 REV. 0

\begin{tabular}{|c|c|c|c|c|}
\hline$\underset{\#}{C \text { Cmpd }}$ & Compound & $\begin{array}{c}\text { CAS }^{1} \\
\text { Number }\end{array}$ & $\begin{array}{c}\text { Average } \\
\left(\mathrm{mg} / \mathrm{m}^{3}\right)\end{array}$ & $\begin{array}{c}\text { Standard } \\
\text { Deviation } \\
\left(\mathrm{mg} / \mathrm{m}^{3}\right)\end{array}$ \\
\hline 56 & Unknown C10 Al kene/Cycloal kane ${ }^{4}$ & & 0.10 & 0.01 \\
\hline 57 & Nitric acid, hexyl ester & $20633-11-8$ & 0.079 & 0.002 \\
\hline 58 & Unknown C10 Alkene/Cycloal kane ${ }^{4}$ & & 0.067 & $<0.01$ \\
\hline 59 & Unknown C10 Alkene/Cycloalkane & & 0.074 & 0.007 \\
\hline 60 & Unknown C11 Alkane & & 0.79 & 0.02 \\
\hline 61 & Unknown C11 Alkane & & 0.21 & 0.01 \\
\hline 62 & Unknown C10 Alkene/Cycloal kane & & 0.56 & 0.01 \\
\hline 63 & Unknown C11 Alkene/Cycloalkane & & 0.12 & 0.001 \\
\hline 64 & Octanenitrile $e^{4}$ & $124-12-9$ & 0.10 & 0.01 \\
\hline 65 & Unknown C11 Alkane & & 0.26 & 0.02 \\
\hline 66 & Unknown C11 Alkane & & 0.15 & 0.01 \\
\hline 67 & Unknown C11 Alkane & & 0.32 & 0.03 \\
\hline 68 & Unknown C11 Alkene/Cycloalkane & & 0.27 & 0.01 \\
\hline 69 & Unknown C11 Diene/Cycloalkene ${ }^{3}$ & & 0.07 & - \\
\hline 70 & Naphthalene, decahydro-, trans- & $493-02-7$ & 0.38 & 0.001 \\
\hline 71 & 1-Undecene & $821-95-4$ & 0.23 & 0.01 \\
\hline 72 & Unknown C11 Alkene/Cycloalkane & & 0.29 & 0.03 \\
\hline 73 & n-Undecane & $1120-21-4$ & 11.29 & 1.06 \\
\hline 74 & Octane, 4-methy $1-^{3}$ & $2216-34-4$ & 0.07 & -- \\
\hline 75 & Unknown C11 Alkene/Cycloalkane & & 0.44 & 0.05 \\
\hline 76 & Unknown C12 Alkane & & 0.21 & 0.02 \\
\hline 77 & Unknown C12 Alkane & & 0.42 & 0.04 \\
\hline 78 & Unknown C11 Diene/Cycloalkene & & 0.22 & 0.06 \\
\hline 79 & Naphthalene, methyl-decahydro & & 0.68 & 0.10 \\
\hline 80 & Cyclohexane, penty1- & $4292-92-6$ & 0.52 & 0.06 \\
\hline 81 & Unknown C12 Alkane & & 0.40 & 0.04 \\
\hline 82 & Naphthalene, methyl-decahydro & & 0.89 & 0.08 \\
\hline 83 & Unknown C12 Alkane & & 0.43 & 0.04 \\
\hline
\end{tabular}


WHC-SD-WM-ER-459 REV. 0

\begin{tabular}{|c|c|c|c|c|}
\hline$\underset{\#}{\text { Cmpd }}$ & Compound & $\begin{array}{c}\text { CAS }^{1} \\
\text { Number }\end{array}$ & $\begin{array}{l}\text { Average } \\
\left(\mathrm{mg} / \mathrm{m}^{3}\right)\end{array}$ & $\begin{array}{c}\text { Standard }{ }^{2} \\
\text { Deviation } \\
\left(\mathrm{mg} / \mathrm{m}^{3}\right) \\
\end{array}$ \\
\hline 84 & Unknown C12 Alkane & & 0.26 & 0.03 \\
\hline 85 & Unknown Ketone & & 0.19 & 0.02 \\
\hline 86 & Unknown C12 Alkene/Cycloalkane & & 0.30 & 0.03 \\
\hline 87 & n-Dodecane & $112-40-3$ & 12.29 & 1.05 \\
\hline 88 & Undecane, 2,6-dimethy1- & $17301-23-4$ & 2.56 & 0.26 \\
\hline 89 & Unknown C13 Alkene/Cycloalkane & & 0.10 & 0.01 \\
\hline 90 & Unknown C13 Alkene/Cycloalkane & & 1.03 & 0.11 \\
\hline 91 & Unknown C12 Alkane & & 0.56 & 0.05 \\
\hline 92 & Unknown C13 Alkene/Cycloal kane ${ }^{4}$ & & 0.39 & 0.04 \\
\hline 93 & Unknown C13 Alkane ${ }^{3}$ & & 0.46 & -- \\
\hline 94 & Unknown C13 Alkane ${ }^{3}$ & & 0.17 & -- \\
\hline 95 & Unknown Al kane ${ }^{4}$ & & 0.17 & 0.02 \\
\hline 96 & Octane, 2,3,7-trimethy1- & $62016-34-6$ & 2.51 & 0.24 \\
\hline 97 & Unknown C13 Alkene/Cycloal kane ${ }^{4}$ & & 0.10 & $<0.01$ \\
\hline 98 & n-Tridecane & $629-50-5$ & $12: 05$ & 0.64 \\
\hline 99 & Unknown C14 Alkene/Cycloalkane & & 0.39 & 0.05 \\
\hline 100 & Unknown Alkane & & 0.37 & 0.04 \\
\hline 101 & Unknown C13 Diene/Cycloal kene ${ }^{4}$ & & 0.096 & 0.005 \\
\hline 102 & Unknown C13 Alkene/Cycloal kane & & 0.56 & 0.06 \\
\hline 103 & Unknown C15 Alkene/Cycloalkane ${ }^{3}$ & & 0.10 & -- \\
\hline 104 & Unknown Alkane ${ }^{4}$ & & 0.10 & 0.01 \\
\hline 105 & Unknown C15 Alkane & & 1.29 & 0.08 \\
\hline 106 & $n$-Tetradecane & $629-59-4$ & 4.44 & 0.16 \\
\hline 107 & Unknown Alkane ${ }^{4}$ & & 0.13 & $<0.01$ \\
\hline 108 & Unknown C15 Alkene/Cycloal kane ${ }^{3}$ & & 0.11 & -- \\
\hline 109 & Unknown C15 Alkene/Cycloal kane ${ }^{3}$ & & 0.13 & - \\
\hline 110 & Unknown Al kane & & 0.32 & 0.01 \\
\hline 111 & $n$-Pentadecane & $629-62-9$ & 0.16 & 0.02 \\
\hline
\end{tabular}


WHC-SD-WM-ER-459 REV. 0

\begin{tabular}{llcl}
\hline \hline $\begin{array}{c}\text { Cmpd } \text { Compound } \\
\#\end{array}$ & $\begin{array}{c}\mathrm{CAS}^{1} \\
\text { Number }\end{array}$ & $\begin{array}{c}\text { Average } \\
\left(\mathrm{mg} / \mathrm{m}^{3}\right)\end{array}$ & $\begin{array}{c}\text { Standard } \\
\text { Deviation } \\
\left(\mathrm{mg} / \mathrm{m}^{3}\right)\end{array}$ \\
\hline \hline Sum of tentatively identified compounds: & 108.7 \\
\hline \hline
\end{tabular}

1. CAS = Chemical Abstract Service.

2. When the analyte was detected in only 2 samples, the entry is the relative difference (i.e., their difference divided by 2 ).

3. Detected in only one sample.

4. Detected in only two samples. 
WHC-SD-WM-ER-459 REV. 0

Table X-8

Tank C-102 Tentatively Identified Organic Compounds in TST Samples

\begin{tabular}{|c|c|c|c|c|}
\hline$\underset{\#}{C m p d}$ & Compound & $\begin{array}{c}\text { CAS }^{1} \\
\text { Number }\end{array}$ & $\begin{array}{l}\text { Average } \\
\left(\mathrm{mg} / \mathrm{m}^{3}\right)\end{array}$ & $\begin{array}{c}\text { Standard } \\
\text { Deviation } \\
\left(\mathrm{mg} / \mathrm{m}^{3}\right) \\
\end{array}$ \\
\hline 1 & Methane, trichlorofluoro & $75-69-4$ & 0.51 & 0.88 \\
\hline 2 & 2-Butanone & $78-93-3$ & 0.55 & 0.95 \\
\hline 3 & Furan, tetrahydro & $109-99-9$ & 0.89 & 0.79 \\
\hline 4 & $\begin{array}{l}\text { 2(3H)-furanone, } \\
\text { dihydro-3,5-dimethy } 1\end{array}$ & $5145-01-7$ & 0.24 & 0.22 \\
\hline 5 & $\begin{array}{l}\text { Cyclobutane, } 1,2 \text {-diethyl-, } \\
\text { trans- \& cis- }\end{array}$ & & 0.15 & 0.27 \\
\hline 6 & Cyclopropane, propyl & $2415-72-7$ & 0.11 & 0.19 \\
\hline 7 & Benzene, ethy 1 & $100-41-4$ & 0.090 & 0.155 \\
\hline 8 & Heptanal & $111-71-7$ & 0.10 & 0.17 \\
\hline 9 & Xylene & $1330-20-7$ & 0.40 & 0.39 \\
\hline 10 & Styrene & $100-42-5$ & 0.11 & 0.19 \\
\hline 11 & Xylene & $1330-20-7$ & 0.12 & 0.21 \\
\hline 12 & C8-Al kanone & & 0.82 & 0.34 \\
\hline 13 & $1,1,2,3$-tetramethyl-cyclohexane $A$ & & 0.22 & 0.20 \\
\hline 14 & Nonane, 4-methy 1 & $17301-94-9$ & 0.12 & 0.20 \\
\hline 15 & 3-Buten-2-01 & $598-32-3$ & 1.1 & 0.48 \\
\hline 16 & Benzene, (1-methylethyl)- & $98-82-8$ & 0.079 & 0.136 \\
\hline 17 & Cyclohexane, 1-methyl-3-propyl & $4291-80-9$ & 0.20 & 0.17 \\
\hline 18 & 2-Decene, (E)- & $20063-97-2$ & 0.14 & 0.13 \\
\hline 19 & Cyclohexane, (3-methyl-pentyl)- & $61142-38-9$ & 0.11 & 0.19 \\
\hline 20 & $\begin{array}{l}\text { Cyclohexane, 1,5-diethyl- } \\
\text { 2,3-dimethyl }\end{array}$ & $74663-66-4$ & 0.095 & 0.165 \\
\hline 21 & Nonane, 2,6-dimethy 1 & $17302-28-2$ & 1.1 & 0.2 \\
\hline 22 & Benzene, 1-propeny 1 & $637-50-3$ & 0.21 & 0.18 \\
\hline 23 & 4,5-Nonadiene & $821-74-9$ & 0.10 & 0.17 \\
\hline 24 & Cyclohexane, (1-methylpropyl)- & $7058-01-7$ & 0.24 & 0.06 \\
\hline 25 & 1,1-dimethyl-2-propylcyclohexane & & 0.30 & 0.03 \\
\hline
\end{tabular}


WHC-SD-WM-ER-459 REV. 0

\begin{tabular}{|c|c|c|c|c|}
\hline$\underset{\#}{\text { Cmpd }}$ & Compound & $\begin{array}{c}\text { CAS }^{1} \\
\text { Number }\end{array}$ & $\begin{array}{l}\text { Average } \\
\left(\mathrm{mg} / \mathrm{m}^{3}\right)\end{array}$ & $\begin{array}{c}\text { Standard } \\
\text { Deviation } \\
\left(\mathrm{mg} / \mathrm{m}^{3}\right)\end{array}$ \\
\hline 26 & Decane, 5-methy 1 & $13151-35-4$ & 0.44 & 0.04 \\
\hline 27 & Decane, 4-methyl & $2847-72-5$ & 0.34 & 0.08 \\
\hline 28 & Decane, 2-methyl & $6975-98-0$ & 1.0 & 0.2 \\
\hline 29 & Naphthalene, decahydro-, trans & $493-02-7$ & 0.53 & 0.10 \\
\hline 30 & Decane, 3-methyl & $13151-34-3$ & 0.53 & 0.03 \\
\hline 31 & Benzene, 1-methy1-2-propyl & $1074-17-5$ & 0.14 & 0.25 \\
\hline 32 & 4-Nonanone & $4485-09-0$ & 0.13 & 0.23 \\
\hline 33 & C4-benzene \& others & & 0.14 & 0.24 \\
\hline 34 & 5-Undecene & $4941-53-1$ & 0.44 & 0.01 \\
\hline 35 & 2-Nonanone & $821-55-6$ & 1.0 & 0.1 \\
\hline 36 & 2-Decene, 4-methy1, (Z) & $74630-30-1$ & 0.11 & 0.19 \\
\hline 37 & 5-Undecene, (E)- & $764-97-6$ & 0.18 & 0.32 \\
\hline 38 & 1-Undecene, 4-methyl & $74630-39-0$ & 0.41 & 0.36 \\
\hline 39 & Cyclopropane, octyl & $1472-09-9$ & 0.62 & 0.12 \\
\hline 40 & Undecane, 5-methyl & $1632-70-8$ & 0.82 & 0.19 \\
\hline 41 & Naphthalene, decahydro-2-methyl & $2958-76-1$ & 0.39 & 0.54 \\
\hline 42 & Undecane, 2,8-dimethyl & $17301-25-6$ & 0.097 & 0.168 \\
\hline 43 & Undecane, 4,8-dimethyl & $17301-33-6$ & 0.083 & 0.143 \\
\hline 44 & Undecane, 3,8-dimethy 1 & $17301-30-3$ & 2.0 & 0.7 \\
\hline 45 & Mixture & & 0.11 & 0.20 \\
\hline 46 & Benzene, (2-methy1-2-propenyl)- & $3290-53-7$ & 0.099 & 0.171 \\
\hline 47 & 1-Dodecene & $112-41-4$ & 0.14 & 0.13 \\
\hline 48 & 5-Undecene, 7-methyl (E)- & $74630-66-3$ & 0.12 & 0.21 \\
\hline 49 & 3-Undecene, 2-methyl, (Z)- & $74630-48-1$ & 1.1 & 1.7 \\
\hline 50 & Methyldecahydronaphthalene & & 3.1 & 0.5 \\
\hline 51 & 6-Methylundecane & $17302-33-9$ & 1.8 & 1.3 \\
\hline 52 & Undecane, 4-methyl & $2980-69-0$ & 1.1 & 0.4 \\
\hline 53 & Undecane, 2-methy1 & $7045-71-8$ & 2.3 & 1.1 \\
\hline
\end{tabular}


WHC-SD-WM-ER-459 REV. 0

\begin{tabular}{|c|c|c|c|c|}
\hline$\underset{\#}{\text { Cmpd }}$ & Compound & $\begin{array}{l}\text { CAS }^{1} \\
\text { Number }\end{array}$ & $\begin{array}{l}\text { Average } \\
\left(\mathrm{mg} / \mathrm{m}^{3}\right)\end{array}$ & $\begin{array}{c}\text { Standard } \\
\text { Deviation } \\
\left(\mathrm{mg} / \mathrm{m}^{3}\right) \\
\end{array}$ \\
\hline 54 & Benzene, pentyl & $538-68-1$ & 0.46 & 0.48 \\
\hline 55 & Undecane, 3-methy 1 & $1002-43-3$ & 1.2 & 0.6 \\
\hline 56 & 4-Undecene, 4-methyl & $61142-40-3$ & 0.99 & 0.64 \\
\hline 57 & Undecane, 3-methyl & $1002-43-3$ & 0.16 & 0.28 \\
\hline 58 & C13-Al kane & & 0.25 & 0.43 \\
\hline 59 & Cyclododecane & $294-62-2$ & 1.3 & 0.2 \\
\hline 60 & $\begin{array}{l}\text { Naphthalene, } \\
\text { decahydro-1,2-dimethyl }\end{array}$ & $3604-14-6$ & 0.71 & 0.18 \\
\hline 61 & 4-Dodecene, (E)- & $7206-15-7$ & 0.30 & 0.12 \\
\hline 62 & Undecane, 2,4-dimethyl & $17312-80-0$ & 0.046 & 0.079 \\
\hline 63 & Undecane, 2,6-dimethy 1 & $17301-23-4$ & 3.4 & 0.2 \\
\hline 64 & Undecane, 4,7-dimethyl. & $17301-32-5$ & 0.43 & 0.05 \\
\hline 65 & $\begin{array}{l}\text { Dimethyl-decahydro naphthalene } \\
+ \text { others }\end{array}$ & & 0.31 & 0.27 \\
\hline 66 & 4-Undecene, 5-methyl- (z)- & $74630-69-6$ & 0.045 & 0.077 \\
\hline 67 & Undecane, 2,10-dimethyl \& others & & 0.14 & 0.24 \\
\hline 68 & Cycopentane, 1-penty1-2-propy 1 & $62199-51-3$ & 0.078 & 0.135 \\
\hline 69 & $\begin{array}{l}\text { Cyclohexane, 2-butyl-1, } \\
\text { 1,3-trimethy? }\end{array}$ & $54676-39-0$ & 1.7 & 0.2 \\
\hline 70 & Undecane, 5-ethy1 & $17453-94-0$ & 0.19 & 0.05 \\
\hline 71 & 3-Hexadecyne & $61886-62-2$ & 0.25 & 0.01 \\
\hline 72 & Cyclohexane, (4-methylpenty1)- & $\begin{array}{r}61142-201- \\
9\end{array}$ & 0.84 & 0.06 \\
\hline 73 & Dodecane, 4-methy 1 & $6117-97-1$ & 0.78 & 0.06 \\
\hline 74 & Dodecane, 2-methyl & $1560-97-0$ & 1.5 & 0.1 \\
\hline 75 & $\begin{array}{l}\text { 2-Hexanone, 3-cyclo- } \\
\text { hexyl iden-4-ethyl }\end{array}$ & & 0.18 & 0.16 \\
\hline 76 & Dodecane, 4,6-dimethy 1 & $61141-72-8$ & 3.8 & 0.4 \\
\hline 77 & $\begin{array}{l}\text { 2-Butenoic acid, } \\
\text { 2-propenyl ester \& others }\end{array}$ & & 0.27 & 0.48 \\
\hline
\end{tabular}


WHC-SD-WM-ER-459 REV. 0

\begin{tabular}{|c|c|c|c|c|}
\hline$\underset{\#}{\text { Compd }}$ & Compound & $\begin{array}{c}\text { CAS }^{1} \\
\text { Number }\end{array}$ & $\begin{array}{l}\text { Average } \\
\left(\mathrm{mg} / \mathrm{m}^{3}\right)\end{array}$ & $\begin{array}{c}\text { Standard } \\
\text { Deviation } \\
\left(\mathrm{mg} / \mathrm{m}^{3}\right) \\
\end{array}$ \\
\hline 78 & Benzene, (1-methylpentyl)- & $6031-02-3$ & 0.15 & 0.26 \\
\hline 79 & Trimethyldecahydronaphthalene & & 0.48 & 0.09 \\
\hline 80 & 3-Undecanone & $2216-87-7$ & 0.13 & 0.23 \\
\hline 81 & 6-Tridecane, 7-methy 7 & $24949-42-6$ & 1.1 & 0.1 \\
\hline 82 & Undecane, 3,8-dimethyl & $17301-30-3$ & 0.055 & 0.096 \\
\hline 83 & Alkane & & 0.16 & 0.16 \\
\hline 84 & Heptane, 3-ethy $1-5$-methy 1 & $52896-90-9$ & 0.19 & 0.33 \\
\hline 85 & Al kane & & 0.10 & 0.17 \\
\hline 86 & Decane, 6-ethy 7 -2-methy 1 & $62108-21-8$ & 0.37 & 0.63 \\
\hline 87 & Undecane, 5-ethy 1 & $17453-94-0$ & 0.48 & 0.45 \\
\hline 88 & $\begin{array}{l}\text { Cyclooctane, 1-methylpropyl- } \\
\text { and others }\end{array}$ & & 0.14 & 0.12 \\
\hline 89 & Cyclooctane, butyl & $16538-93-5$ & 0.055 & 0.096 \\
\hline 90 & C4-Cyclohexane & & 0.095 & 0.165 \\
\hline 91 & C12-a 7 kene and $\mathrm{C}$-benzene & & 0.19 & 0.16 \\
\hline 92 & C8-cyclohexane & & 0.41 & 0.29 \\
\hline 93 & C14-alkene & & 0.32 & 0.14 \\
\hline 94 & C7-Cyclohexane & & 0.93 & 0.06 \\
\hline 95 & Tridecane, 4-methy 1 & $26730-12-1$ & 0.51 & 0.11 \\
\hline 96 & Dodecane, 3-methy 1 & $17312-57-1$ & 0.29 & 0.51 \\
\hline 97 & Tridecane, 2-methyl & $1560-96-9$ & 0.70 & 0.22 \\
\hline 98 & C8-Cyclohexene & & 0.30 & 0.26 \\
\hline 99 & 5-Undecanone, 2-methyl & $50639-02-6$ & 0.13 & 0.22 \\
\hline 100 & Dodecane, $2,7,10$-trimethy 1 & $74645-98-0$ & 2.6 & 0.2 \\
\hline 101 & Heptane, 2-phenyl & $2132-84-5$ & 0.24 & 0.27 \\
\hline 102 & C8-Cyclohexane & & 0.043 & 0.074 \\
\hline 103 & 3-Dodecanone & $1534-27-6$ & 0.35 & 0.12 \\
\hline 104 & Tetradecane & $629-59-4$ & 4.5 & 1.8 \\
\hline 105 & Tridecane, 4,8-dimethyl & $55030-62-1$ & 0.29 & 0.51 \\
\hline
\end{tabular}


WHC-SD-WM-ER-459 REV. 0

\begin{tabular}{|c|c|c|c|c|}
\hline$\underset{\#}{C \text { Cmpd }}$ & Compound & $\begin{array}{l}\text { CAS }^{1} \\
\text { Number }\end{array}$ & $\begin{array}{l}\text { Average } \\
\left(\mathrm{mg} / \mathrm{m}^{3}\right)\end{array}$ & $\begin{array}{c}\text { Standard } \\
\text { Deviation } \\
\left(\mathrm{mg} / \mathrm{m}^{3}\right) \\
\end{array}$ \\
\hline 106 & 1,1'-biphenyl & $92-52-4$ & 0.92 & 0.86 \\
\hline 107 & $\begin{array}{l}\text { 2-Hexenoic acid, } \\
\text { 2-hexenyl ester, (E,E)- }\end{array}$ & $54845-28-2$ & 0.052 & 0.090 \\
\hline 108 & 1,1-Bipheny1,2-methy 1 & $643-58-3$ & 0.48 & 0.57 \\
\hline 109 & $\begin{array}{l}\text { Benzene, } 1,1^{\prime} \text {-methylenebis- } \\
\text { and others }\end{array}$ & & 0.24 & 0.22 \\
\hline 110 & Tridecane, 4-methyl & $26730-12-1$ & 0.087 & 0.151 \\
\hline 111 & C8-cyclohexane & & 0.068 & 0.117 \\
\hline 112 & Dodecane, $2,6,11$-trimethy 1 & $31295-56-4$ & 0.055 & 0.096 \\
\hline 113 & Tridecane, 4,8-dimethy1 & & 0.047 & 0.081 \\
\hline 114 & Hexadecane & $544-76-3$ & 0.56 & 0.07 \\
\hline 115 & 2-Undecanone, 6,10-dimethy 1 & $105-42-0$ & 0.059 & 0.103 \\
\hline 116 & Dimethyl-naphthalene & & 0.17 & 0.29 \\
\hline 117 & Benzene, (1-methylhepty1)- & $777-22-0$ & 0.031 & 0.053 \\
\hline 118 & Dodecane, 2-methy1-8-propyl & $55045-07-3$ & 0.45 & 0.78 \\
\hline 119 & Pentadecane, 2-methy 1 & $1560-93-6$ & 0.056 & 0.096 \\
\hline 120 & 5-Undecanone, 2-methy 1 & $50639-02-6$ & 0.15 & 0.26 \\
\hline 121 & 3-Tridecanone & $1534-26-5$ & 0.21 & 0.14 \\
\hline 122 & Pentadecane & $629-62-9$ & 0.77 & 0.63 \\
\hline 123 & 1,1'-Bipheny1, 2-methy 1 & $643-58-3$ & 0.067 & 0.116 \\
\hline 124 & 1,1'-Bipheny1, 2-methy 1 & $643-58-3$ & 0.039 & 0.067 \\
\hline 125 & 9H-Fluorene & $86-73-7$ & 0.077 & 0.134 \\
\hline 126 & Benzenesul fonamide, $\mathrm{N}$-buty 1 & $3622-84-2$ & 0.23 & 0.04 \\
\hline
\end{tabular}

1. CAS = Chemical Abstract Service. 


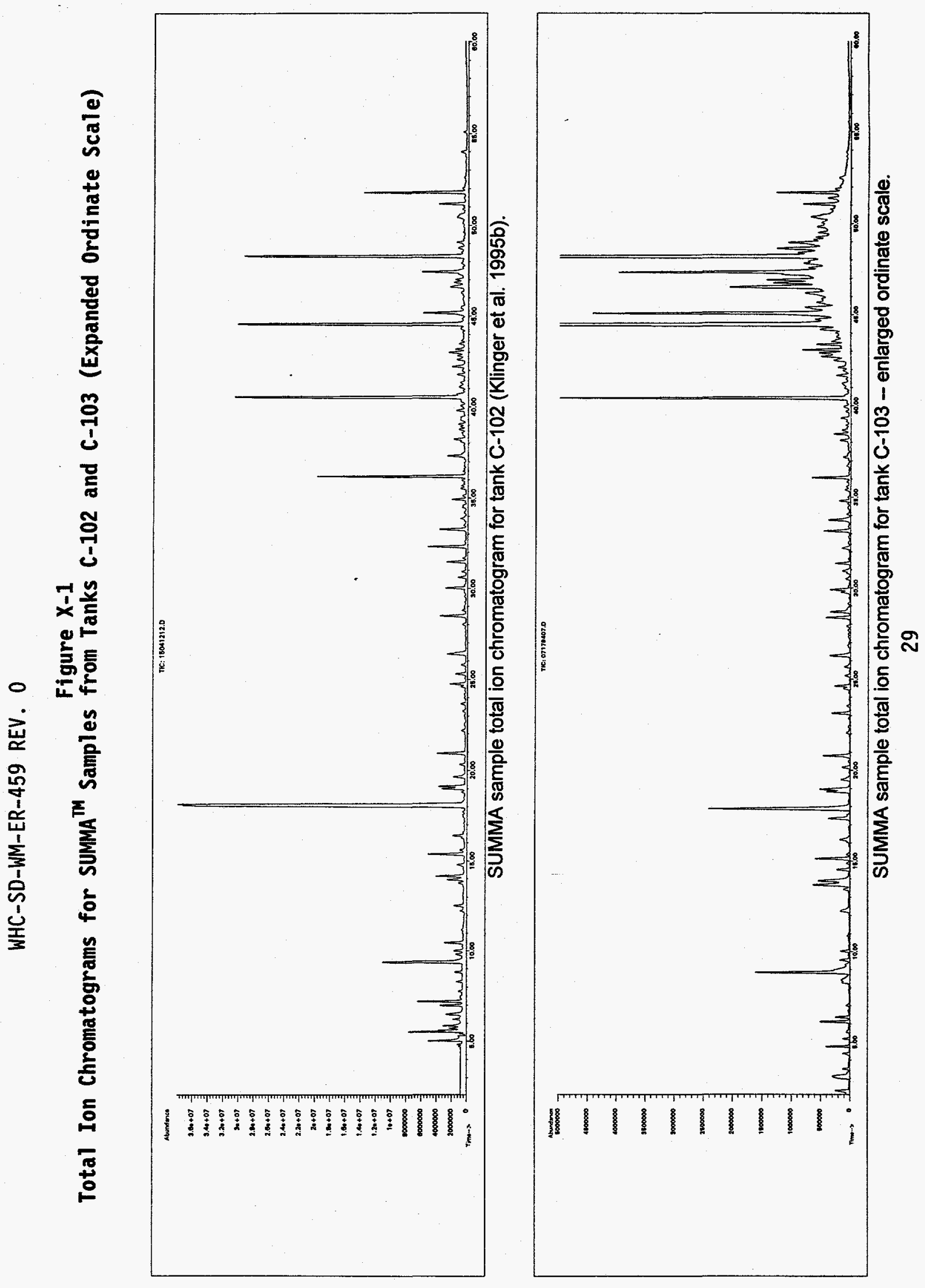



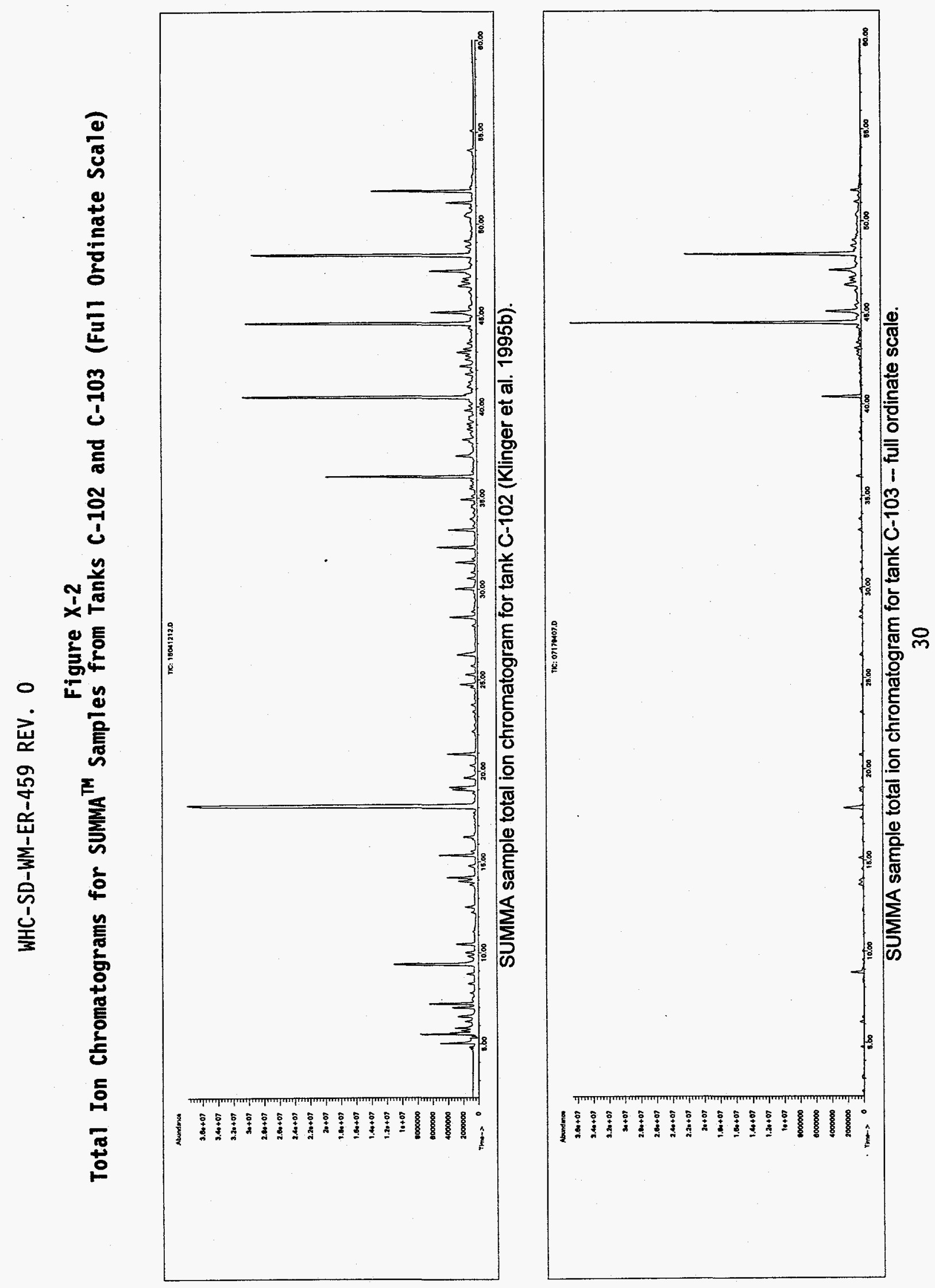
WHC-SD-WM-ER-459 REV. 0

Figure $X-3$

Total Ion Chromatograms for SUMMA Samples from Tanks C-102 and C-101

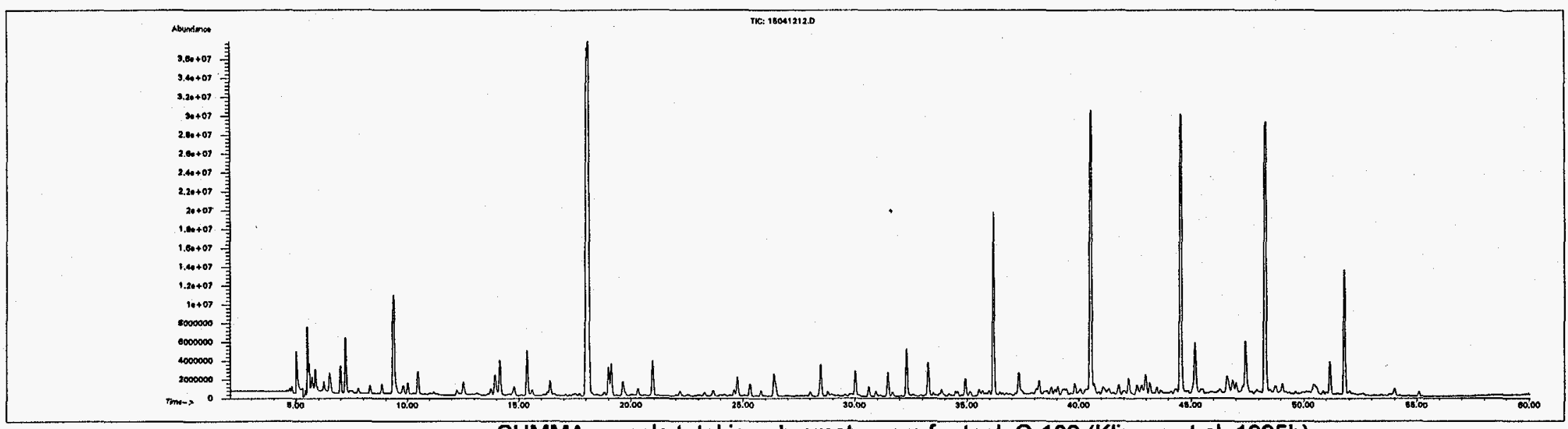

SUMMA sample total ion chromatogram for tank C-102 (Klinger et al. 1995b).

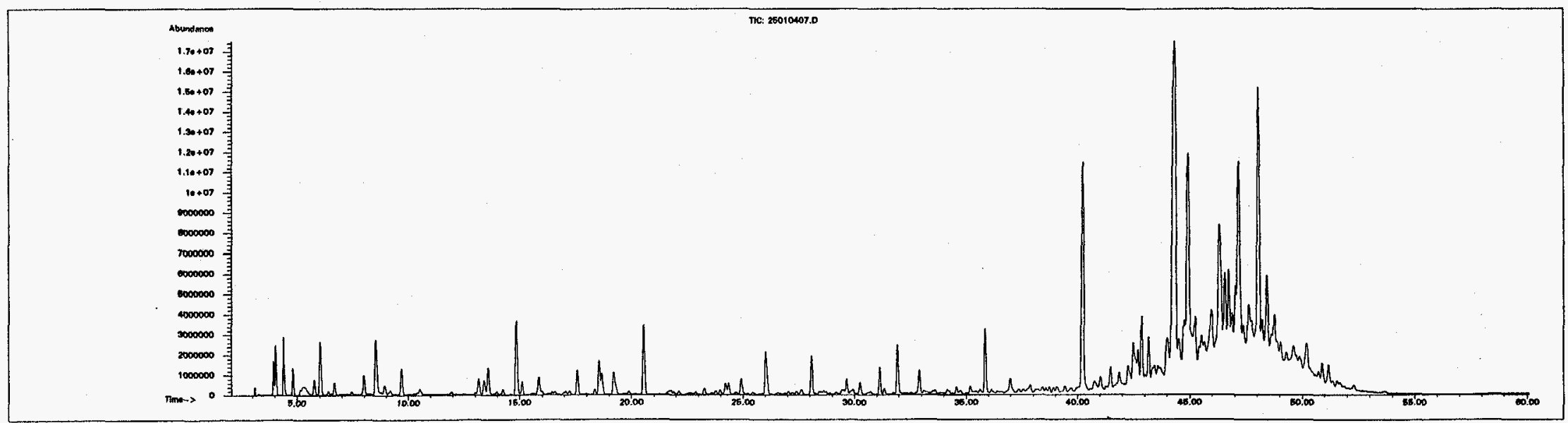

SUMMA sample total ion chromatogram for tank C-101 (Lucke et al. 1995a). 


\section{X.4 REFERENCES}

Anderson, J. D., 1990, A History of the 200 Area Tank Farms, WHC-MR-0132, Westinghouse Hanford Company, Richland, Washington.

Campbel1, J. A., R. M. Bean, K. L. Wahl, G. M. Wong, K. E. Bell, K. B. Wehner, A. D. Rice, R. J. Ray, D. B. Bechtold, B. R. Wels, R. W. Schroeder, J. W. Ba11, B. D. Valenzuela, J. M. Frye, S. L. Fitzgerald, P. P. Bachelor, B. Griffin, R. K. Fuller, A. B. Benally, and S. M. Parong, 1995, Analysis of Samples from Hanford Waste Tanks 241-C-102, 241-BY-108, and 241-C-103, PNL-10531, UC-601, Pacific Northwest Laboratory, Richland, Washington.

Carothers, K. G., 1988, Tank 103-C Transaction History - Post January 1976, (internal memorandum 13331-88-600 to D. A. Dodd, G. L. Dunford, G. N. Hanson, A. W. Lilly, and R. E. Van der Cook, September 22), Westinghouse Hanford Company, Richland, Washington.

Conrad, R. B., 1994, Engineering Evaluation of alternatives for Treatment of Tank 241-C-103 Vapor Space, WHC-SD-WM-ES-281, Rev. 0, Westinghouse Hanford Company, Richland, Washington.

EPA 1988, Compendium of Methods for the Determination of Toxic Organic Compounds in Ambient Air, PB90-127374, U.S. Environmental Protection Agency, Washington, D.C.

Hendrickson, R. W., 1995, Tank Vapor Characterization Oak Ridge National Laboratories Quality Assurance Assessment, TWRSQA-95-0012, Westinghouse Hanford Company, Richland, Washington.

Huckaby, J. L., 1994, Tank 241-C-103 Headspace Flammabi7ity, WHC-EP-0734 Rev. 1. Westinghouse Hanford Company, Richland, Washington.

Huckaby, J. L., 1995a, Tank 241-C-101 Vapor Sampling and Analysis TCR Chapter, WHC-SD-WM-ER-458, Westinghouse Hanford Company, Richland, Washington.

Huckaby, J. L., 1995b, Waste Tank Headspace Gas and Vapor Characterization Reference Guide, WHC-SD-WM-ER-430 Rev. 0, Westinghouse Hanford Company, Richland, Washington.

Huckaby, J. L., and M. S. Story, 1994, Vapor Characterization of Tank 241-C103, WHC-EP-0780 Rev. 0, Westinghouse Hanford Company, Richland, Washington.

Jenkins, R. A, A. B. Dindal, C. E. Higgins, C. Y. Ma, M. A. Palausky, J. T. Skeen, and C. K. Bayne, 1994a, Analys is of Tank 241-C-102 Headspace Components, ORNL-CASD-FR-241C102.95, Rev. 0, Oak Ridge National Laboratory, Oak Ridge, Tennessee. 
Jenkins, R. A, A. B. Dindal, C. E. Higgins, C. Y. Ma, M. A. Palausky, and J. T. Skeen, 1994b, Analysis of Tank 241-C-101 Headspace Components, Oak Ridge National Laboratory, Oak Ridge, Tennessee.

Jenkins, R. A, A. B. Dinda1, C. E. Higgins, C. Y. Ma, J. T. Skeen, and R. R. Smith, 1994c, Analysis of Tank 24I-C-103 Headspace Components from Sampling Job 7B, Oak Ridge National Laboratory, Oak Ridge, Tennessee.

Klinger, G. S., T. W. Clauss, M. W. Ligotke, K. H. Pool, R. B. Lucke, B. D. McVeety, K. B. Olsen, 0. P. Bredt, J. S. Fruchter, and S. C. Goheen, 1995a, Vapor Space Characterization of Waste Tank 241-C-102: Resu7ts from Samples Collected on 8/23/94, PNL-xxxxx UC-606, Pacific Northwest Laboratory, Richland, Washington.

Klinger, G. S., T. W. Clauss, M. W. Ligotke, K. H. Pool, R. B. Lucke, B. D. McVeety, 0. P. Bredt, J. S. Young, M. McCulloch, J. S. Fruchter, and S. C. Goheen, 1995b, Vapor Space Characterization of Waste Tank 241-TX-105: Results from Samples Collected Through the Vapor Sampling System on 12/20/94, PNL-xxxxx UC-606, Pacific Northwest Laboratory, Richland, Washington.

Lucke, R. B., M. W. Ligotke, K. H. Pool, T. W. Clauss, A. K. Sharma, B. D. McVeety, M. McCulloch, J. S. Fruchter, and S. C. Goheen, 1995a, Vapor Space Characterization of Waste Tank 241-C-108: Results from Samples Collected Through the Vapor Sampling System on 8/5/94, PNL-XXXXX UC-606, Pacific Northwest Laboratory, Richland, Washington.

Lucke, R. B., T. W. Clauss, M. W. Ligotke, K. H. Pool, B. D. McVeety, J. S. Young, M. McCulloch, J. S. Fruchter, and S. C. Goheen, 1995b, Vapor Space Characterization of Waste Tank 241-C-101: Results from Samples Collected Through the Vapor Sampling System on 9/1/94, PNL-xxxxx UC-606, Pacific Northwest Laboratory, Richland, Washington.

Mahlum, D. D., J. Y. Young, and R. E. Weller, 1994, Toxicologic Evaluation of Analytes from Tank 231-C-103, PNL-10189, Pacific Northwest Laboratory, Richland, Washington.

McVeety, B. D., T. W. Clauss, M. W. Ligotke, K. H. Pool, R. B. Lucke, G. S. Klinger, J. S. Young, M. McCulloch, J. S. Fruchter, and S. C. Goheen, 1995, Vapor Space Characterization of Waste Tank 241-BY-108: Results from Samples Collected on 10/27/94, PNL-xxxxx UC-606, Pacific Northwest Laboratory, Richland, Washington.

NIOSH 1995, NIOSH Pocket Guide to Chemical Hazards, U.S. Department of Health and Human Resources, National Institute for Occupational Safety and Health, Cincinnati, Ohio.

Osborne, J. W., and J. L. Huckaby, 1994, Program Plan for the Resolution of Tank Vapor Issues, WHC-EP-0562 Rev. 1, Westinghouse Hanford Company, Richland, Washington. 
Osborne, J. W., J. L. Huckaby, T. P. Rudolph, E. R. Hewitt, D. D. Mahlum, J. Y. Young, and C. M. Anderson, 1994, Data Quality Objectives for Generic In-Tank Health and Safety Issue Resolution, WHC-SD-WM-DQ0-002, Westinghouse Hanford Company, Richland, Washington.

Pool, K. H, and R. M. Bean, 1994, Analysis of Liquid Samples from Hanford Waste Tank 241-C-103, PNL-9403 UC-601, Pacific Northwest Laboratory, Richland, Washington.

Rasmussen, R. A., 1994a, Air Samples Collected at Waste Tank 241-C-102 on August 23, 1994 by Westinghouse Hanford in 6-L SS SUMMA Canisters, Oregon Graduate Institute of Science and Technology, Beaverton, Oregon.

Rasmussen, R. A., 1994b, Air Samples Collected at Waste Tank 241-C-111 on September 13, 1994 by Westinghouse Hanford in 6-L SS SUMMA@ Canisters, Oregon Graduate Institute of Science and Technology, Beaverton, Oregon.

Rasmussen, R. A., and W. Einfeld, 1994, Hanford Tank 103-C Analyses and Method Validation Development Phase, SAND94-1807, Sandia National Laboratories, Albuquerque, New Mexico.

WHC 1995, Vapor and Gas Sampling of Single-Shell Tank 241-C-102 Using the Vapor Sampling System, WHC-SD-WM-RPT-127, Westinghouse Hanford Company, Richland, Washington. 